\title{
Mündlich-kommunikativer Deutschunterricht in Norwegen und dessen Umsetzung von Lehrkräften an Jugend- und weiterführenden Schulen in der Region Agder
}

Sebastian Baak

Tangen videregående skole, Kristiansand

\section{Zusammenfassung}

Die vorliegende Untersuchung wurde im Rahmen der Lehrerausbildung (Praktisk-pedagogisk utdanning) im Hauptfach Deutsch als Fremdsprache (DaF) an der Universität Agder in Kristiansand, Norwegen durchgeführt. Ziel der Studie war es zu untersuchen, welche theoretischen und methodischen Grundlagen Lehrkräfte verwenden, um die Lernenden zur mündlichen Beteiligung im Fremdsprachenunterricht anzuregen und welche Strategien sie für die Beurteilung der mündlichen Leistungen verwenden. Ausgehend von einer soziokulturelltheoretischen Perspektive wurde die mündlich-kommunikative Komponente im Deutschunterricht beleuchtet. Die Untersuchung wurde mit Hilfe von semi-strukturierten Interviews mit fünf DaF-Lehrkräften der Klassenstufen 8-13 durchgeführt. Die Befunde zeigen, dass alle Lehrkräfte den Anspruch der mündlichen Beteiligung am Sprachunterricht für sinnvoll erachten. Das didaktische Handeln der Lehrkräfte im Unterricht wird jedoch selten von wissenschaftlich fundierten Theorien bestimmt. Vielmehr scheinen die subjektiven Theorien der Lehrkräfte eine größere Rolle zu spielen. Die Lehrkräfte weisen ein vielseitiges Repertoire an Unterrichtsformen auf, die zur mündlichen Beteiligung im Unterricht anregen und es ihnen ermöglichen, die mündlichen Leistungen der Schüler zu beurteilen. Es bleibt offen, inwieweit die Distanz zwischen wissenschaftlichen Theorien und dem praktischen Unterricht generalisierbar ist und inwieweit dies ein Problem für die Wissensaneignung der Schüler sein kann.

\section{Schlüsselwörter}

Spracherwerb, Zweitsprache, Schule, mündlich, Lehrkräfte, Deutschunterricht 


\section{Einleitung}

Mit der Gleichstellung von klassischer und realfachlicher Bildung in Norwegen erhielten vor ungefähr 150 Jahren moderne Fremdsprachen, wie Englisch, Französisch und Deutsch, Einzug in den Unterricht und verdrängten zunehmend die klassischen Sprachen Latein und Griechisch (vgl. Bjørke, Dypedahl, Haukås, 2018, S. 20). Allerdings blieb die Art und Weise des Sprachunterrichts an Schulen weiterhin meist klassisch: Auch beim Unterricht der neuen Sprachen wurden in erster Linie anspruchsvolle Texte gelesen und die Grammatik vor allem durch das Übersetzen geübt (vgl. Trebbi, 2015, S. 104). Dieser als „Grammatik- und Übersetzungsmethode“ bezeichnete Unterricht wurde zudem hauptsächlich in der Muttersprache der Lernenden durchgeführt (Tornberg, 2015, S. 35). Schon im Lehrplan Normalplan für Stadtvolksschulen 1939 (Normalplan for byfolkeskolen 1939) rückte aber das Sprechen in der neuen Sprache stärker in den Mittelpunkt: „Sprechen auf Englisch sollte die wichtigste Unterrichtsform sein, sowohl bei der ersten Erklärung der Worte als auch beim Einüben ihres späteren Gebrauchs“"1 , heißt es etwa in den Richtlinien für das Fach Englisch für die sechste Klasse (Kirke- og undervisningsdepartementet, 1939, S. 228). Dieser, für die Zeit, recht fortschrittliche Ansatz wird aber teilweise wieder durch umfangreiche und eingrenzende Anweisungen für schriftliche Übungen relativiert. So findet sich im Lehrplan aus dem Jahr 1939 eine Liste mit mehr als 1000 Vokabeln, die die Schülerinnen und Schüler auswendig lernen sollen (vgl. Kirke- og undervisningsdepartementet, 1939, S. 231). Erst ab Mitte der 1970er Jahre, mit der Einführung des Lehrplans Musterplan für Grundschulen (Mønsterplan for grunnskolen) von 1974, des Lehrplans für weiterführende Ausbildung (Læreplan for videregående opplæring) von 1976 und des Musterplans für Grundschulen (Mønsterplan for grunnskolen) von 1987, veränderte sich allmählich der Fremdsprachenunterricht an Norwegens Schulen. Neue Ergebnisse der Sprachlernforschung genauso wie die Sprachpolitik des Europarats beeinflussten diese Entwicklung (vgl. Bjørke, Dypedahl, Haukås, 2018, S. 22). So heißt es im Musterplan für Grundschulen von 1974 zum Thema Fremdsprachen: „Der Unterricht in der zweiten Fremdsprache hat seinen Ausgangspunkt in der Sprache als ein Mittel zur mündlichen Kommunikation und Kontakt

\footnotetext{
1 ,Samtale på engelsk bør være den viktigste undervisningsform, både til den første forklaring av ordene og til den seinere innøving i å bruke dem“ (Kirke- og undervisningsdepartementet, 1939, S. 228).
} 
mit anderen Menschen“"2 (Kirke- og undervisningsdepartementet, 1974, S. 313). Die Lehrer werden hier aufgefordert, verschiedene Kommunikationsarten mit den Lernenden zu üben und dieses „Fertigkeitstraining sollte nicht leblos und mechanisch sein, sondern vielmehr sollten die Schüler es als sinnvoll und stimulierend erleben"33 (Kirke- og undervisningsdepartementet, 1974, S. 313). Im Musterplan von 1987 werden unter anderem reale Kommunikationssituationen hervorgehoben. Im Kapitel für die zweite Fremdsprache heißt es: „Die Schüler sollen die Möglichkeit erhalten, die Sprache in einer möglichst realen Kommunikation mit anderen innerhalb und außerhalb der Schule zu verwenden, zu üben und zu entwickeln““4 (Kirke- og undervisningsdepartementet, 1987, S. 295ff.).

Heutzutage fokussieren Dokumente wie das Lehrplanwerk (Læreplanverket), das sogenannte Kunnskapsløftet (LK06) (vgl. Utdannings- og forskningsdepartementet, 2006) und der gemeinsame europäische Referenzrahmen für Sprachen (Europarat, 2001) auf eine Reihe von kommunikativ gerichteten Lernzielen und schreiben einen alltagsnahen und relevanten Gebrauch von Sprachen in der Herangehensweise beim Erlernen von Fremdsprachen vor. Dies soll auch gemeinsames Handeln, Verständnis und Respekt zwischen verschiedenen Kulturen fördern (vgl. Bjørke et al., 2018, S. 23).

\section{Theoretischer und empirischer Hintergrund}

Grundlage dieser Untersuchung bilden vor allem die gesetzlichen, nationalen Richtlinien des Fremdsprachenunterrichts (Abschnitt 2.1), fachdidaktische und lerntheoretische Überlegungen zum Fremdsprachenunterricht (Abschnitt 2.2), sowie internationale Studien zur mündlichen Kommunikation im Unterricht allgemein und im Fremdsprachenunterricht im Besonderen (Abschnitt 2.3).

\footnotetext{
2 ,Undervisningen i det andre fremmedspråk tar sitt utgangspunkt i språket som et middel til muntlig kommunikasjon og kontakt med andre mennesker" (Kirke- og undervisningsdepartementet, 1974, S. 313) 3 ,ferdighetstreningen må ikke bli livløs og mekanisk, men bør oppleves av elevene som meningsfullt og stimulerende“" (Kirke- og undervisningsdepartementet, 1974, S. 313)

4 „Elevene skal få bruke, øve på og utviklet språket i mest mulig reell kommunikasjon med andre både i og utenfor skolen“ (Kirke- og undervisningsdepartementet, 1987, S. 295f.)
} 


\subsection{Lehrplan für Fremdsprachen (FSP1-01) ${ }^{5}$}

Das Erlernen von Fremdsprachen hat nach Ansicht der norwegischen Regierung einen hohen

Stellenwert: „Eine kleine Sprachgesellschaft wie Norwegen braucht viele Menschen mit guten

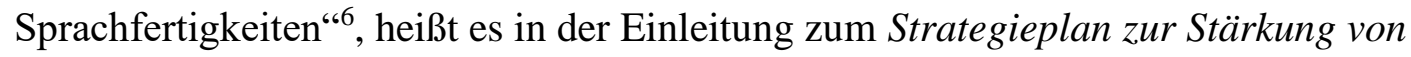
Fremdsprachen in der Grundschulbildung (Strategi for styrking av fremmedspråk i grunnopplæringen 2005-2009) des norwegischen Kultusministeriums

(Kunnskapsdepartementet, 2007, S. 5). Die geltenden Richtlinien für den Unterricht von Fremdsprachen sind durch die zuständige Ausbildungsbehörde (Utdanningsdirektoratet) im Lehrplan für Fremdsprachen FSP 1-01 (Læreplan i fremmedspråk FSP1-01) festgelegt. Dort wird unter der Überschrift „Grundlegende Fertigkeiten“ festgehalten: „Sich schriftlich und mündlich in einer Fremdsprache auszudrücken, ist zentral für die Kompetenzentwicklung in einer Fremdsprache [...] $]^{\text {"7 }}$ (FSP1-01, 2006, S. 4). Mündliche und schriftliche Kommunikation sind somit gleichgestellt. Als Kompetenzziele gibt der Lehrplan FSP1-01 unter anderem vor, dass auf der Sprachniveaustufe I die Lernenden ,an einfachen, spontanen Gesprächssituationen teilnehmen und unterschiedliche Themenbereiche mündlich präsentieren können“"8 (FSP1-01, 2006, S. 6). Diese Kompetenzziele werden auf Sprachniveaustufe II dann insofern erweitert, dass die Lernenden „,an spontanen Gesprächen zu unterschiedlichen und gegenwärtigen Themen teilnehmen können, aktuelle und fächerübergreifende Themen mündlich präsentieren, sowie Erlebnisse, Ansichten, Einstellungen, Wünsche und Gefühle ausdrücken können“99 (FSP1-01, 2006, S. 7).

\subsection{Lerntheoretische und fachdidaktische Überlegungen zur mündlichen Beteiligung} Sprache wird generell einerseits als wichtig für die Kommunikation zwischen Menschen angesehen, zum anderen ist sie wichtig für Lern- und Verstehensprozesse (vgl. Imsen, 2014, S. 218ff). Dem Erlernen einer Fremdsprache kommt zudem eine weitere Rolle hinzu, indem

\footnotetext{
${ }^{5}$ Zum Zeitpunkt dieser Untersuchung ist bereits ein neues Lehrplanwerk in Arbeit. Das Lehrplanwerk „Fagfornyelsen“ (Utdanningsdirektoratet, 2019a) wird die Richtlinien von LK06 ab 2020 sukzessive ersetzen.

${ }^{6}$ „Et lite språksamfunn som Norge trenger mange mennesker med gode språkferdigheter“ (Kunnskapsdepartementet, 2007, S. 5)

7 ,Å kunne uttrykke seg skriftlig og muntlig i fremmedspråk er sentralt i utviklingen av kompetanse i fremmedspråket [...]“ (FSP1-01, 2006, S. 4)

8 ,delta i enkle, spontane samtalesituasjoner [og] presentere ulike emner muntlig“ (FSP1-01, 2006, S. 6)

${ }^{9}$,delta i spontane samtaler om ulike temaer og aktuelle emner [,] presentere aktuelle og tverrfaglige emner muntlig [og] gi uttrykk for opplevelser, synspunkter og holdninger, ønsker og emosjoner“ (FSP1-01, 2006, S. 7)
} 
es das Verstehen ,der Welt' erleichtert und die Kommunikation mit Personen anderer Nationen und verschiedenen Kulturen möglich macht. In Norwegen wird die mündliche und schriftliche Sprache in neueren norwegischen Lehrplänen als gleichwertig angesehen (vgl. Imsen, 2014, S. 229). Verschiedene Lerntheoretiker haben sich mit der Sprache auseinandergesetzt. Als besonders relevant für diese Arbeit hat sich jedoch der russische Psychologe Lev Vygotskij (1896-1934) herausgestellt. Vygotskijs Überzeugung in Bezug auf die Sprache war, dass die Sprache die Kommunikation zwischen Personen mediiert (vgl. Moen, 2013, S. 255) und dass es eine Relation zwischen Kognition und der Sprache in Form eines Prozesses gibt, der zwischen dem Gesprochenen und dem Gedachten hin und her geht (vgl. Imsen, 2014, S. 219). Sein Gedankengut hat einen deutlichen Einfluss auf die pädagogische Praxis gehabt und zu einem generell starken Fokus auf sprachliche Aktivitäten, Sprachentwicklung und Dialog im Unterricht beigetragen (vgl. Imsen, 2014, S. 220). In Bezug auf das Erlernen von Zweit- bzw. Fremdsprachen vertritt Vygotskij die Auffassung, dass Fremdsprachenunterricht auch zum stärkeren Bewusstsein der eigenen Muttersprache beiträgt und dass er zu einer gegenseitigen Bereicherung der beiden Sprachen führt (vgl. Imsen, 2014, S. 230). Um dies zu illustrieren, zitiert er Goethe: ,[...] wer eine Fremdsprache nicht kennt, kennt in Wirklichkeit auch nicht seine eigene“(Vygotskij, 1962, S. 110).

Um eine Sprache zu lernen, muss man mit ihr vertraut werden. Wichtig ist dabei der mündliche Input durch die Lehrperson. Gleich von der ersten Stunde an sollen sich die Lernenden an die für sie neue Sprache gewöhnen und sie auch sprechen, selbst wenn es sich zunächst nur um Phrasen handelt (vgl. Lightbown \& Spada, 2013, S. 98). Der Sprachunterricht soll kommunikativ und praktisch sein (vgl. Bjørke et al., 2018, S. 82). Verschiedene Sprachlernansätze, wie zum Beispiel die systemisch-funktionale Grammatik von Michael Halliday (systemisk-funksjonalistisk lingvistikk), stützen diese kommunikativmündliche Ausrichtung. Allerdings ist die mündliche Sprachfertigkeit bei einer Fremdsprache eine komplexe Angelegenheit. Viele Kompetenzen wie „Aussprache, Intonation, Hörverständnis, Grammatik, Wortschatz, soziolinguistische und soziokulturelle Kenntnisse“ (Tornberg, 2015, S. 190) müssen gleichzeitig aktiviert und abgerufen werden können. Auch generelle Lerntheorien sprechen für eine mündliche Beteiligung im Unterricht. Die konstruktivistische Perspektive hebt beispielsweise hervor, dass Lernen in der aktiven Auseinandersetzung mit dem Lernstoff geschieht. Kommunikation, auch mündlich, ist dabei 
ein zentraler Faktor (vgl. Säljö, 2013, S. 61ff.). Seit vielen Jahren wird ein hohe mündlichkommunikative Beteiligung von Schülern im Fremdsprachen-Unterricht angestrebt, da insbesondere die aktive Auseinandersetzung mit Lerninhalten als einer der wichtigsten Faktoren für erfolgreiche Lernprozesse der Lernenden angesehen wird.

\subsection{Empirische Untersuchungen zur mündlichen Beteiligung im Unterricht}

Die mündliche Beteiligung der Lernenden im Unterricht ist in allen Schulfächern wünschenswert, nicht nur im Fremdsprachenunterricht. Ein hoher Schüleranteil am Unterrichtsgespräch ist scheinbar aber nicht die Regel. So konnte zum Beispiel in Fächern des mathematisch-naturwissenschaftlichen Bereichs eine nur mäßige Schülerbeteiligung festgestellt werden. Internationale Studien haben hier unter anderem gezeigt, dass es in diesen Fächern nicht ungewöhnlich ist, dass die Lehrkraft 75\%-80\% der Redeanteile im Unterricht übernimmt. Das zeigen Befunde der beiden TIMSS-Videostudien von 1995 und 1999 und der IPN-Videostudie für den Physikunterricht ${ }^{10}$ (vgl. Kleinschmidt-Schinke, 2018, S. 158f.). Neuere fachdidaktische Erkenntnisse, und die in Norwegen geltenden Richtlinien der staatlichen Bildungsbehörden, leiten sich aus dem Gemeinsamen europäischen Referenzrahmen für Sprachen ab. Das legt die Vermutung nah, dass europaweit auf die mündliche Unterrichtsbeteiligung der Lernenden großen Wert gelegt wird. Studien zeigen aber, dass dies auch in anderen Ländern schwierig ist. Dies belegt beispielsweise die DESIStudie über den Englisch-Unterricht in Deutschland: „An ihr nahmen 105 Englischklassen teil, die das gesamte Leistungsspektrum repräsentieren. [...] Anhand der Videodaten lässt sich nachweisen, dass die Lehrkraft im Durchschnitt doppelt so viel spricht wie alle Schüler zusammen“ (Helmke et al., 2008, S. 350). Ähnliche Ergebnisse hat eine Studie auch für Norwegen gezeigt (vgl. Heimark, 2007). Diese Erkenntnisse sind nicht nur aus fachdidaktischen Gründen ungünstig, sondern auch deshalb problematisch, weil damit schulische Richtlinien durch die Lehrkräfte in der Praxis auch nicht umgesetzt werden. Als eine von fünf Grundfertigkeiten fordert der Lehrplan für Fremdsprachen FSP1-01 etwa einen hohen Anteil der mündlichen Komponente durch die Schüler. Es muss aber vermutet werden, ohne hier den Nachweis führen zu können, dass eher von einer stark lehrerlastigen Verteilung

\footnotetext{
${ }^{10}$ TIMSS = Trends in International Mathematics an Science Study; IPN = Leibniz-Institut für die Pädagogik der Naturwisschenschaften und Mathematik an der Universität Kiel
} 
der Sprechanteile im Unterricht auszugehen ist. In diesem Fall würden die Lehrkräfte den Forderungen aus dem Lehrplan für Fremdsprachen FSP1-01 nicht nachkommen.

\subsection{Bewertung der mündlichen Leistung der Schüler im Unterricht}

Schüler in Norwegen haben Anspruch auf eine Bewertung ihrer Leistung im Unterricht. Im

Bildungsgesetz („Opplæringsloven“) heißt es dazu: „Schüler im öffentlichen Primär- und Sekundarbereich I sowie Schüler, Lehrlinge, Praktikanten und Auszubildende im Sekundarbereich II haben das Recht, nach den Regeln dieses Kapitels bewertet zu werden.

Das Recht auf Bewertung umfasst sowohl das Recht auf laufende Bewertung und abschließende Bewertung als auch das Recht auf Dokumentation des Bildungsgangs“"11 (Opplæringsloven, 2017, §3-1). Oft wird dabei zwischen formativer und summativer Beurteilung unterschieden ${ }^{12}$.

Meines Wissens liegt keine ausreichende Forschung zum Thema der mündlichkommunikativen Beteiligung im Deutschunterricht in Norwegen vor. Aus meiner eigenen Arbeit als Deutschlehrer an Schulen in der südlichen norwegischen Region Agder und aus Gesprächen mit erfahrenen Deutschlehrern, lässt sich der Eindruck erwecken, dass Schülerinnen und Schüler in Norwegen die Gelegenheiten, losgelöst von grammatikalischen Regeln, einfach ,drauflos` zu reden, wie es Lightbown \& Spada (2013, S. 308 ff.) empfehlen, nicht nutzen. Ein mündlich-kommunikativ geprägter Deutschunterricht in Norwegen scheint, unabhängig von Niveaustufen, schwierig. Damit ergibt sich für die Lehrkräfte auch das Problem der Überprüfung und Bewertung der mündlichen Sprachfertigkeit und -kenntnisse der Schüler. Bei einer generell geringen mündlichen Beteiligung im Unterricht sind die Bedingungen für Feedback und Rückmeldung begrenzt. Somit stellt sich die Frage, nach welchen Kriterien und Ansprüchen die Lehrkräfte dann Noten für die mündliche Mitarbeit der Lernenden vergeben.

\footnotetext{
11 „Elevar i offentleg grunnskoleopplæring og elevar, lærlingar, praksisbrevkandidatar og lærekandidatar i offentleg vidaregåande opplæring har rett til vurdering etter reglane i dette kapitelet. Retten til vurdering inneber både ein rett til undervegsvurdering og sluttvurdering og ein rett til dokumentasjon av opplæringa.“ (Opplæringsloven, 2017, §3-1)

${ }^{12}$ Aufgrund des Umfangs dieser Studie wird auf diesen Teilaspekt nicht weiter eingegangen. Vgl. hierzu vertiefend Imsen, 2016, S. 477.
} 


\section{Problemstellung und Forschungsfragen}

Die übergeordnete Problemstellung dieser Untersuchung lautet daher: Wie verstehen und praktizieren Lehrkräfte, die Deutsch als Fremdsprache in Norwegen unterrichten, den Anspruch eines mündlich-geprägten und kommunikativen Unterrichts?

Forschungsfrage 1: Wie verstehen die Lehrkräfte die Richtlinien im Lehrplan für Fremdsprachen FSP1-01 in Bezug auf einen mündlich-kommunikativ geprägten Unterricht?

Forschungsfrage 2: Wie setzen die Lehrkräfte die Richtlinien bezüglich der mündlichen Unterrichtsbeteiligung methodisch und fachdidaktisch um?

Forschungsfrage 3: Welche Herausforderungen sehen die Lehrkräfte bei der Umsetzung bezüglich der Richtlinien, einen mündlich-kommunikativen Unterricht zu gestalten?

Forschungsfrage 4: Welche Herausforderungen sehen die Lehrkräfte bei der Umsetzung bezüglich der Richtlinien, die Leistungen der Schüler in einem mündlich-kommunikativen Unterricht zu bewerten?

\section{Durchführung der Studie}

In diesem Kapitel wird die in der Studie verwendete Methode beschrieben, nämlich den Prozess Methodenwahl (Abschnitt 4.1), die Auswahl der Informanten (Abschnitt 4.2), die Aufbereitung und Systematisierung der Daten (Abschnitt 4.3), sowie die Reliabilität und Validität der Studie (Abschnitt 4.4).

\subsection{Methode}

Bei der Studie handelt es sich um eine explorative Untersuchung mit einer qualitativen Methode. Die Wahl einer qualitativen Methode eignet sich im Umfeld Schule gut: Der Schulalltag ist eine Abfolge zahlreicher, oft parallellaufender, sozialer Prozesse. Die qualitative Forschung bietet die Möglichkeit, sich dieser sozialen Handlungen auf besondere Weise wissenschaftlich zu nähern, indem sich der Forscher offen für das zeigt, was die 
Teilnehmenden, in diesem Fall die Lehrenden, sagen und beschreiben (Postholm, 2010, S. 9).

Bei der Frage nach Auffassungen, Meinungen und Ideen, wie es in der vorliegenden Untersuchung der Fall ist, spielt das Interviewgespräch eine besondere Rolle: „Subjektive Bedeutungen lassen sich nur schwer aus Beobachtungen ableiten. Man muss hier die Subjekte selbst zur Sprache kommen lassen“ (Mayring, 2002, S. 66). Ein weiterer Vorteil des Interviews ist der persönliche Charakter der Befragung. Dadurch kann eine offene Gesprächssituation entstehen (Postholm \& Jacobsen, 2017, S. 68). Es gibt unterschiedliche Formen des Forschungsinterviews, die auf verschiedene Art und Weise strukturiert sind. Für diese Arbeit wurde die Form des ,semistrukturierten Interviews“ gewählt. Diese Interviewform lässt einerseits den Befragten die Freiheit, mit seinen eigenen Worten auf die gestellte Frage zu antworten, andererseits hat der Forscher bei einem semistrukturierten Interview die Möglichkeit, Nachfragen zu stellen (,oppfølgingsspørsmål“) (Postholm \& Jacobsen, 2017, S. 75). Damit ähnelt das semistrukturierte Interview einer Gesprächssituation (Mayring, 2002, S. 67), ist aber flexibler zu handhaben als ein stark strukturiertes Interview. Gleichzeitig ist es aber strukturierter und standardisierter als ein offenes Interview.

Der semistrukturierte Ansatz hat hier seinen Ausgangspunkt in einem bewusst formulierten Interviewleitfaden, dessen Fragen bestimmte Themenpunkte abdecken und auf den im Rahmen des Interviews immer wieder zurückgegriffen wird. Die Leitfadenstruktur leitet sich von der Problemstellung und den Forschungsfragen ab. Zusätzliches Nachfragen dienen dazu, weitere vertiefende Informationen zu erhalten oder den Befragten auf wieder zurück auf den ursprünglichen Themenbereich zu bringen (Mayring, 2010, S. 269). Diese Interviewstruktur wird auch als „Tre-med-grener“-Modell (Postholm, 2010, S. 79), also „Baum-mit-Ästen“-Modell, beschrieben.

Im Fall dieser Untersuchung wurden vier Forschungsfragen als Ausgangspunkt genommen. Um den Forschungsfragen nachgehen zu können, wurden zu jeder Forschungsfrage Interviewfragen formuliert. Der Interviewleitfaden wurde in Tabellenform angelegt, in dem die Forschungsfragen und die neun dazugehörigen Interviewfragen enthalten waren (siehe Anhang A). Des Weiteren wurden mögliche Nach- oder Vertiefungsfragen formuliert, die den jeweiligen Interviewfragen zugeordnet werden konnten. Aus praktischen Gründen wurden schon im Vorwege Zusatzfragen formuliert, um während der einzelnen 
Interviews schnell, präzise und möglichst gleichlautende Nachfragen stellen zu können. Alle neun Interviewfragen wurden den Informanten im Laufe der einzelnen Interviews gestellt.

\subsection{Auswahl der Lehrkräfte und Durchführung der Datenerhebung}

Die Forschungsethik umfasst sowohl rechtliche als auch ethische Regeln bei der Verarbeitung personenbezogener Daten, die eingehalten werden müssen. Der Forschungsprozess und die Ergebnisse müssen fair und genau dargestellt werden. Dazu gehört auch, dass Informanten über den Ablauf der Untersuchung informiert und über die Nutzung und Aufbewahrung ihrer Angaben aufgeklärt werden.

Für die Untersuchung wurden fünf Lehrkräfte interviewt. Bei den Männern und Frauen handelt es sich ausnahmslos um Fremdsprachenlehrer im Fach Deutsch mit mehrjähriger Unterrichtserfahrung in Klassen der Sekundarstufe I (,ungdomsskole“, 8.-10. Klasse) und der Sekundarstufe II (,videregående skole“, 11.-13. Klasse). Die Lehrkräfte arbeiten an verschiedene Schulen an unterschiedlichen Standorten in der Region Agder. Keiner der fünf interviewten Lehrkräfte hat Deutsch als Muttersprache. Alle sind seit mehreren Jahren an ihren Schulen als Fremdsprachenlehrkräfte tätig. Die Interviews wurden anonymisiert protokolliert.

Eine Woche vor dem Interview wurden die Informanten schriftlich über das Projekt informiert. Dabei erhielten sie Informationen über Hintergrund und Zielrichtung der Studie. Ihnen wurden auch die vier Forschungsfragen genannt, allerdings nicht die dazu ausgearbeiteten Interviewfragen oder mögliche Vertiefungsfragen. Dadurch sollte verhindert werden, dass sie sich schriftlich auf das Interview vorbereiten und dadurch möglicherweise nicht offen für Vertiefungsfragen sind. Sowohl in dem Schreiben als auch kurz vor Beginn des Interviews wurden die Informanten darüber aufgeklärt, dass die Studie anonym ist und sie jederzeit die Möglichkeit haben, von der Teilnahme daran zurückzutreten. Von der Registrierung der Studie bei der NSD ${ }^{13}$ wurde abgesehen, weil keine personenbezogenen Daten erhoben wurden. In der Studie werden die teilnehmenden Lehrer als Lehrer A, B, C, D und $\mathrm{E}$ bezeichnet. ${ }^{14}$

\footnotetext{
${ }^{13}$ NSD = Norsk senter for forskningsdata (Norwegisches Zentrum für Forschungsdaten)

${ }^{14}$ Die Berufsbezeichnung „Lehrer“ wird geschlechtsneutral verwendet und bezieht sich, wenn nicht ausdrücklich markiert, auf Männer und Frauen gleichermaßen.
} 
Zur Qualitätssicherung wurde ein Pilotinterview mit einem Informanten durchgeführt, um mögliche Unklarheiten in der Fragestellung zu erkennen und gegebenenfalls Verbesserungen vornehmen zu können. Dies war nicht notwendig, so dass alle Interviews, auch das Pilotinterview, auf Basis des gleichen Interviewleitfadens geführt wurden. Die Interviews mit den insgesamt fünf Lehrkräften erfolgten innerhalb von vierzehn Tagen im März und April 2019. Die Interviews wurden als Einzelinterviews und auf Norwegisch geführt.

\subsection{Datenaufbereitung und -systematisierung}

Die Interviews wurden gesichtet und in eine Tabelle übertragen. Dies erfolgte in der Originalsprache Norwegisch (Bokmål). Inhalte, die den anonymen Charakter der Datenerhebung möglicherweise verletzten könnten, wurden nicht übertragen. Die Lehrkräfte wurden als Lehrer A, Lehrer B usw. benannt. Durch die Anonymisierung sind die Vorgaben der NSD erfüllt.

Die nun vollständig anonymisierten, niedergeschriebenen Interviews hat einen Umfang von 9924 Wörtern. Für die Auswertung wurde eine Tabelle angefertigt, die die systematische Herangehensweise an das Datenmaterial erleichtern sollte. Den vier Forschungsfragen wurden in der Nachbarspalte den jeweils dazugehörigen Interviewfragen zugeordnet. Die Aussagen der fünf Lehrer, wurden jeweils in einem einzelnen Kasten zusammengefasst und der passenden Forschungsfrage gegenübergestellt. Nachfragen bei einigen Interviews wurden als solche gekennzeichnet und den jeweiligen Lehrern beigeordnet (siehe Anhang B).

Nach dem Übertragen der Rohdaten erfolgte die Verringerung des Materialumfanges durch Zusammenfassung und Verallgemeinerung der Aussagen der Lehrkräfte (Postholm \& Jacobsen, 2017, S. 104). Als Technik fand hier die systematische zusammenfassende Inhaltsanalyse Anwendung: „Bei der systematischen zusammenfassenden Inhaltsanalyse wird das Allgemeinheitsniveau des Materials vereinheitlicht und schrittweise höher gesetzt“". (Mayring, 2002, S. 95). Aus Gründen der Übersichtlichkeit wurden die generalisierten und reduzierten Inhalte in einer neuen Spalte der Tabelle den Lehreraussagen gegenübergestellt. Diese zusammengefassten Aussagen wurden dem übergeordneten Zusammenhang (Theorie, Empirie) in einer weiteren Spalte der Tabelle zugeordnet. 


\section{4 Überlegungen zur Reliabilität und Validität der Studie}

Um eine gute Qualität der Studie zu gewährleisten, wurde die methodische Ausrichtung sorgfältig gewählt. Das semistrukturierte Interview als methodisches Instrument hat den Vorteil, dass sich im Laufe des Interviews eine gesprächsähnliche Situation entwickelt. Für die Beantwortung der Forschungsfragen ist das notwendig, denn hier ist die Frage nach Kenntnissen und Überzeugungen der Lehrkräfte, salopp gesagt, was in ihren Köpfen vorgeht, zentral. Zudem besteht die Möglichkeit, bei unklaren Antworten noch Nachfragen zu stellen. Diese Möglichkeiten hat man mit anderen Forschungsinstrumenten, wie z.B. Beobachtung oder Fragebogen, nicht.

Ausgewählt wurden Lehrer beider Geschlechter, die jeweils über eine mehrjährige Lehrerfahrung im Fremdsprachenfach Deutsch verfügen. Allen wurde Gelegenheit gegeben, sich im gewissen Rahmen auf das Interview vorzubereiten. Durch die Anonymität sollte eine höchstmögliche Offenheit der Befragten im Interview erreicht werden.

Die Interviews wurden in der Muttersprache der Befragten, auf Norwegisch, durchgeführt. Dadurch sollten Schwierigkeiten bei möglichen fachlichen Begrifflichkeiten in Bezug auf Lehrplan und Richtlinien umgangen werden.

Aufgrund der relativ geringen Stichprobengröße von fünf Lehrkräften wurde darauf Wert gelegt, dass alle Lehrer von unterschiedlichen Schulen kommen. Dies ist wichtig, weil jede Schule ihre eigene Lehrkultur hat, die sich möglicherweise in Auslegung der Richtlinien und Unterrichtspraktiken niederschlägt. Mit Lehrkräften von fünf verschiedenen Schulen bestand damit die Möglichkeit, ein größeres Maß an unterschiedlichen und voneinander unabhängigen Handlungsrepertoires zu untersuchen.

Um die Genauigkeit und die Nachprüfbarkeit der Analysen sicherzustellen, wurde bei der Aufarbeitung der gewonnenen Daten und der Analyse Schritt für Schritt vorgegangen und die Arbeiten sorgfältig dokumentiert. Grundlage ist die Analyse durch eine systematische und strukturierte Vorgehensweise mit Hilfe eines Ablaufmodells, wie es in der qualitativen Forschung empfohlen wird (Mayring, 2002, S. 146).

Da es sich um eine Untersuchung von begrenztem Umfang handelt, wird man die Befunde nicht generalisieren können. Allerdings können die Ergebnisse als eine Pilotstudie in Betracht gezogen werden, die einen wichtigen Impuls geben können, um weitere Forschung 
im Bereich des mündlich-kommunikativen Fremdsprachenunterrichts zu initialisieren. Dies könnte etwa mit einer größeren Anzahl an Informanten und überregional durchgeführt werden, was bei dieser Untersuchung nicht möglich war.

\section{Analyse}

Im folgenden Abschnitt werden die transkribierten Aussagen der fünf Lehrkräfte analysiert. Ziel ist es, einer Antwort auf die übergeordnete Problemstellung „Wie verstehen und praktizieren Lehrkräfte, die Deutsch als Fremdsprache in Norwegen unterrichten, den Anspruch eines mündlich-geprägten und kommunikativen Unterrichts?“ näher zu kommen. Dazu werden die Forschungsfragen abschnittsweise näher beleuchtet.

\subsection{Der Lehrplan FSP1-01 mit Blick auf mündlich-orientierten Unterricht}

Die erste Forschungsfrage in dieser Untersuchung beschäftigt sich mit den Richtlinien im Lehrplan für Fremdsprachen FSP1-01 und wie die Lehrkräfte diese Richtlinien mit Blick auf einen mündlich-orientieren Unterricht verstehen. In ihren Antworten sind sich alle fünf Lehrer einig: Mündliche Kommunikation ist ein zentraler und wichtiger Bestandteil beim Erwerb einer Fremdsprache. Die ersten Schritte in einer neuen Sprache geschehen selten schriftlich: „[...] in der Lage zu sein, mit Leuten zu sprechen ... das ist vielleicht das, was die meisten Leute damit in Verbindung bringen [...] nicht zwangsläufig das Schreiben von Fremdsprachen“, sagt Lehrer D im Interview. Lehrer C weist daraufhin, dass der Klassenraum ein guter Ort ist, um die mündliche Kommunikation zu üben. Es sei wichtig, dass man von Angesicht zu Angesicht sprechen kann und ,daher ist es wichtig, während des Unterrichts mündlich zu kommunizieren und im Klassenzimmer zu üben, damit man es im späteren Leben auch verwenden kann", so Lehrer C. Beide Lehrer betonten, dass die Kommunikation zwischen Lehrer und Schülern sowie zwischen den Schülern untereinander einen wichtigen sozialen Aspekt beinhalten, der das Lernen der neuen Sprache unterstützt.

Auf die Frage, welche Richtlinien im Lehrplan auf einen mündlich-kommunikativen Unterricht hinweisen, zeigt sich, dass die befragten Lehrkräfte einen guten Überblick über die im Lehrplan genannten Kompetenzziele haben, auch wenn sie diese Ziele nicht wortwörtlich wiedergeben können. Lehrer A und C nennen „spontane Gespräche“ als stärksten mündlichen 
Aspekt in den Kompetenzzielen. Lehrer C erklärt, dass die Lernenden auch „Gefühle und Erfahrungen“" ausdrücken sollen und sich über fächerübergreifende Themen mündlich austauschen sollen. Nach Auffassung von Lehrkraft C lassen Art und Umfang der im Lehrplan genannten Kompetenzziele einen mündlichen Anteil am Unterricht von 50 Prozent zu. Diese Einschätzung teilt Lehrkraft B aus fachlichen Gründen nicht. Auch sie hält es für wünschenswert, einen hohen mündlich-kommunikativen Anteil im Unterricht zu haben, sie sieht aber einen Zwang, gerade im Unterricht auf Niveaustufe I, einen Fokus auf die Vermittlung von Grammatik zu legen, um den Lernenden den Übergang von Niveaustufe I zu Niveaustufe II zu ermöglichen. Nach Aussagen von Lehrer B wird Grammatikunterricht in erster Linie nicht in der neuen Fremdsprache, sondern aus Verständnisgründen auf Norwegisch durchgeführt. Zudem hat dieser Unterricht einen hohen schriftlichen Anteil.

Lehrkraft D fokussiert neben dem Hinweis auf „spontane Gespräche“ vor allem auf die Kompetenzziele „Sprache, Kultur und Gesellschaft“. Diese Kompetenzziele sind ihrer Ansicht nach stark mündlich geprägt, unter anderem deshalb, weil die Lernenden „im Sprachunterricht dann Sätze oder Phrasen lernen, die typisch für den deutschen Sprachraum“ sind. Wie hoch der mündliche Anteil am Unterricht sein soll, ist im Lehrplan nicht ausdrücklich genannt. Die Lehrkräfte leiten aus den Kompetenzzielen des Lehrplans einen unterschiedlich hohen mündlich-orientierten Unterrichtsanteil ab. Während Lehrer C den mündlichen Anteil bis zu 50 Prozent sieht, ist Lehrer E deutlich zurückhaltender und sagt im Interview, dass ,,circa ein Fünftel bis ein Viertel der Kompetenzziele mündlich geprägt sind, entsprechend plane ich diesen Anteil auch im Unterricht ein“. Auf die Frage wie die Lehrer die Richtlinien mit Hinblick auf mündlich-orientierten Unterricht verstehen oder interpretieren, wird vor allem Lehrer A konkret:

[...] in Bezug auf meinen Unterricht habe ich es so eingerichtet, dass alle wissen, dass jede Person in jeder Stunde Deutsch sprechen muss. [...] Ich fange auf Deutsch an und spreche über den Stundenablauf und so weiter, und dann müssen alle Schüler miteinander sprechen, zwei und zwei, oder drei und drei oder vier und vier Schüler zusammen. Jeder muss einmal in der Stunde sprechen - laut.

Lehrer $\mathrm{C}$ und $\mathrm{E}$ sehen auch das Üben der Aussprache als einen wichtigen mündlichen Bestandteil des Unterrichts. Dabei werden in erster Linie Texte laut gelesen. Wie Lehrer C erklärt, nimmt sie dann diese Übungen häufig als Ausgangspunkt, um im Anschluss über den 
Inhalt der Texte zu sprechen. Dabei können die Schüler dann auf neu gelernte Worte zurückgreifen, die ein Gespräch erleichtern.

Allgemein sehen die Lehrer im Lehrplan aber keine konkreten Hinweise oder Anleitungen auf welche Weise und mit welchen konkreten Elementen sie den mündlich kommunikativen Anteil im Unterricht gestalten sollen: „Ich meine, da steht nun nichts Spezielles drin, das müssen wir dann selbst herausfinden“, sagt zum Beispiel Lehrer D. Lehrer E formuliert mit Blick auf den neuen Lehrplan, der ab 2020 in Kraft treten soll, die Hoffnung, dass „ein größerer Fokus auf das Mündliche und weniger auf das Schriftliche gelegt wird“".

\subsection{Die methodische und fachdidaktische Umsetzung der Richtlinien}

Die zweite Forschungsfrage setzt sich damit auseinander, wie die Lehrkräfte methodisch und fachdidaktisch die Richtlinien bezüglich des mündlich-kommunikativen Unterrichts umsetzen. Bei der Gestaltung der Unterrichtsstunden sticht eine große Gemeinsamkeit der Lehrer hervor: Unterricht muss variiert sein: „Es ist wichtig mit Variationen zu arbeiten, so dass es nicht immer das Gleiche ist [...] Ich mache nicht das Gleiche jede Stunde mit Blick auf mündliche Aktivitäten“, sagt Lehrer A. Auch Lehrer E betont, dass er verschiedene Unterrichtselemente einsetzt. Die in den Kompetenzzielen des Lehrplans FSP1-01geforderte Fähigkeit der Schüler in Niveaustufe I und II, an spontanen Gesprächen teilzunehmen, wird häufig und sehr unterschiedlich geübt. Lehrer A ändert nicht nur das Thema, sondern lässt die Schüler auch Platz und Sitznachbarn wechseln, ,denn sie mögen es auch mal mit anderen Mitschülern zu sprechen und deshalb setzte ich sie dann um“. Ein weiteres Element, das bei einigen Lehrern Anwendung findet, ist das sogenannte ,Speeddating ${ }^{6}$. Dabei sitzen sich die Schüler gegenüber und stellen sich gegenseitig auf Deutsch Fragen, auf die sie abwechselnd antworten. Nach kurzer Zeit, häufig anderthalb oder zwei Minuten, wechselt ein Teil der Schüler den Platz und das gegenseitige Fragen und Antworten beginnt von vorn. Beim ,Speeddating' gebe es eine gute Möglichkeit, Alltagssituationen mit unterschiedlichen Mitschülern auszuprobieren, sagt Lehrer B. Nicht alle Lehrer arbeiten mit vollkommen spontanen mündlichen Aktivitäten: „Ich mag es, wenn die Schüler sich mit einem Text vorher beschäftigen, ihn lesen und ihn einige Male auch gehört haben,“ sagt z.B. Lehrer C, „und dann beginnen die Schüler miteinander über den Text zu sprechen, zu zweit oder in größeren 
Gruppen“. Aus Sicht von Lehrer C ist dies zielführender, weil selbst bei Schülern der Niveaustufe II der Wortschatz für spontane Gespräche häufig nicht ausreicht. Durch das Lesen eines Textes erhalten die Schüler hingegen zusätzliche Worte und Formulierungen, die sie dann im Anschlussgespräch gut einsetzen können. Lehrer D hält spontane Gespräche vor allem bei Anfängerklassen für schwierig und versucht deshalb durch das Lernen von Phrasen oder durch Rollenspiele, einfache Gesprächssituationen zu erzeugen. In diesem Zusammenhang nennt Lehrer D auch das Singen von Liedern als eine Möglichkeit, um mit den Schülern die deutsche Aussprache spielerisch einzuüben. Die Ideen für die unterschiedlichen Unterrichtsinhalte bekommen die Lehrer auf ganz verschiedene Art und Weise. Dazu gehören Anregungen aus Lehrbüchern oder Kursen der Lehrbuchhersteller, Tipps von Kollegen oder auch Internetforen. Lehrer A und E erzählen, dass sie neue Ideen ausprobieren, selbst evaluieren und entsprechende Notizen machen, um darauf später auf die gewonnenen Erfahrungen und Erkenntnisse zurückzugreifen. Lehrer D überträgt Erfahrungen aus dem Englischunterricht auf den Deutschunterricht und hat damit gute Erfahrungen gemacht.

Bei der Frage, nach welchen methodischen und fachdidaktischen Überlegungen sie vorgehen, fällt es den Lehrkräften schwer zu antworten. Es entsteht der Eindruck, dass es für die Lehrer zweitrangig ist, ob sie ihr Handeln mit Hilfe einer bestimmten pädagogischen und fachdidaktischen Theorie erklären können: „,... ] jetzt ist es ja eher das Praktische als die Theorie, die im Vordergrund steht, aber einige Theorien fordern ja, dass sie [die Schüler] aktiv sein sollen, glaube ich“, sagt Lehrer A etwas unsicher. Andere Lehrer nennen schlagwortartig allgemeine pädagogische Prinzipien. So nennt Lehrkraft B das didaktische Relationsmodell und Lehrer D die kognitive Meisterlehre im Interview. Allerdings versäumen es beide im Laufe des Gesprächs, näher darauf einzugehen. Andere Lehrer nennen fachdidaktische Methoden. So erzählen die Lehrkräfte C, A und D, dass sie in ihrem Unterricht mit Phrasen, von Sprachdidaktikern auch „Chunks“ genannt, arbeiten: „Etwas, was ich seit gut zwei Jahren mache ist, dass ich ihnen [den Schülern] Phrasen, also ,chunks“ beibringe. Die müssen sie dann richtig pauken, lieber als einzelne Vokabeln. [...] Dann geht das Reden auch leichter“, sagt Lehrer C. Lehrkraft A übt mit den Schülern Floskeln, zum Beispiel „Wie geht es dir? - Mir geht es gut!“. „Die wiederhole ich häufig, so dass die Schüler sie dann anwenden können“, so Lehrer A. Lehrkraft E setzt auf Vertrauen und ein 
gutes Verhältnis zu den Schülern, um ihnen die nötige Sicherheit und Selbstsicherheit zu geben, in der Klasse auch laut miteinander Deutsch zu sprechen - Lehrkraft E nennt es selbst „Lustprinzip“. Ihre Schüler sollen dazu nicht gedrängt werden, aber sie begrüßt es, wenn einige „Lust“ haben, Deutsch vor der Klasse zu sprechen. Lehrer A legt bezüglich der mündlichen Sprache weniger Wert auf grammatikalische Regeln als bei der geschriebenen Sprache. Er sagt: „,wir Deutschlehrer können auch zu sehr darauf bestehen, dass das Gesagte immer richtig sein muss. Ich sage den Schülern normalerweise immer , wir sind unterwegs ‘ ich spreche nicht perfekt, ihr sprecht nicht perfekt - wir sind dabei, diese Sprache zu lernen“".

Die Ideen und Konzepte, die die Lehrer im Unterricht einsetzen oder ausprobieren, funktionieren unterschiedlich gut. Lehrer E setzt häufig digitale Werkzeuge ein, so wie es in den Kompetenzzielen für beide Niveaustufen des Fremdsprachenunterrichts gefordert wird. Zum Beispiel sollen die Schüler selbstgemachte Filme mit dem Mobiltelefon machen: „Film ist eine Methode, die ich wirklich mehr verwenden sollte. Die Schüler haben Spaß und ich höre ein bisschen öfter Deutsch - und es gibt einige, die sonst nicht oft Deutsch sprechen“, sagt Lehrer E. Schwierigkeiten gibt es aus Sicht von Lehrer A, wenn die Schüler an ihre sprachlichen Grenzen stoßen: „Wenn die deutschen Worte fehlen oder zu viele in der Klasse sich nicht vorbereitet haben, dann sagen die Schüler den ersten Satz auf Deutsch, sprechen danach aber auf Norwegisch weiter“, so Lehrer A, „und wenn man beginnt, überall zu helfen, dass funktioniert dann nicht.“ Auch Lehrer B hält den eingeschränkten Wortschatz für ein Problem, das das beste Unterrichtskonzept durcheinanderbringen kann. Wenn es aber ein Thema gibt, das die Schüler begeistert, dann läuft es gut, was auch Lehrer C hervorhebt: „Vielleicht wenn sie ein Thema selbst wählen können, oder dass sie sich für ein Thema besonders interessieren und darüber reden oder über ihren Alltag sprechen. Ich finde, dass kann sich wirklich lohnen.“

\subsection{Herausforderungen bei der Durchführung mündlich-orientieren Unterrichts}

Die dritte Forschungsfrage beschäftigt sich mit den Herausforderungen, mit denen sich die befragten Lehrer konfrontiert sehen, wenn sie einen mündlich orientierten Unterricht gestalten. Die unterschiedlichen Leistungsniveaus der Schüler scheinen eine markante Herausforderung für die Lehrkräfte zu sein. Für Lehrer E bedeutet das, dass die Unterrichtsaktivitäten eine große Bandbreite und Variation aufweisen müssen, um sowohl 
fachlich starken als auch fachlich schwächeren Schülern gerecht zu werden. Dabei sei es nicht einfach, mündliche Aufgaben und Methoden zu finden, die die Schüler gleichermaßen animieren, mehr Deutsch zu reden, sagt Lehrer A. Das habe bei ihr dazu geführt, dass sie im Vergleich zu früher, weniger Deutsch im Unterricht spricht: „Aber ich denke auch, dass man als Lehrer müde wird, wenn es immer wieder schwache Schüler gibt, die nichts verstehen und nur mit ,Hä?‘ antworten“.

Eine Herausforderung bei der Planung von mündlich-kommunikativer Unterricht ist auch die Tatsache, dass das Wissen der Schüler regelmäßig überprüft wird. Prüfungen sind aber in der Hauptsache schriftlicher Natur - dadurch fühlen sich einige Lehrer gedrängt, das Schreiben besonders zu üben: ,[Es] gibt [einen] starken Druck für die Schüler, gut zu schreiben, sehr viel Grammatik, mit der die Schüler zu kämpfen haben. Man hat das Gefühl, dass man im Vergleich zu allem, was von den Kompetenzzielen erwartet wird, der Großteil sich um das Schreiben dreht", sagt Lehrer C. Auch Lehrer A beschreibt das Gefühl bei vielen Schülern, „dass die Prüfung im Hintergrund steht und ... dann wird notwendigerweise viel geschrieben. Manchmal wünschte ich, wir hätten Unterricht, der sich nicht mit der Prüfung oder nicht der Abschlussprüfung befasst ...einfach Deutsch lernen, nur zum Spaß!“ Deutsch als eine neue Fremdsprache zu erlernen, ist nach Ansicht von Lehrer B auch deshalb eine Herausforderung, weil die Schüler zu wenig der neuen Sprache ausgesetzt sind. Die Schüler sprechen sie häufig nur im Unterricht, also zwei bis maximal vier Stunden in der Woche: „Das Problem bei [der Fremdsprache] Deutsch ist, dass man der Sprache so wenig ausgesetzt ist. Die Schüler bekommen nicht genügend Vokabeln, um die Sprache richtig zu verwenden.“ Als Gegenbeispiel nennt B die englische Sprache, die die Schüler über das Fernsehen, Kino oder auch PC-Spiele ab frühester Jugend hören. Die Aussprache und die Wortbedeutung werden durch Fernsehen und die eingespielten Untertitel fast täglich geübt. Einige Lehrer empfinden die Stundenanzahl zu knapp bemessen. Ich bräuchte eigentlich doppelt so viele Stunden, damit die Schüler richtig Deutsch lernen, sagt Lehrkraft E. Gerade mit Blick auf die Prüfungen hält sie es für problematisch, dass die Schüler mündliche und schriftliche Prüfungen ablegen müssen: „Ich finde, dass die Zeit zu kurz ist, um sowohl eine mündliche als auch eine schriftliche Prüfung abzulegen“. Lehrer E ist deshalb der Meinung, dass für Niveaustufe I eine mündliche Prüfung ausreichend wäre und erst ab Niveaustufe II auch 
schriftlich geprüft werden sollte. Die staatlichen Richtlinien und die Kompetenzziele im Lehrplan legen großen Wert auf einen mündlich geprägten Unterricht.

Folgende Frage ergibt sich somit: Ist es unter diesen Umständen denn realistisch, diese Ziele und Vorgaben in Bezug auf mündliche Sprachkompetenz auch im Unterricht umsetzen zu können? Die für die mündlichen Fertigkeiten gesetzten Ziele sind aus Sicht von Lehrer C für die Schüler zu hoch: „Eine Sache ist, einen Text zu üben, darüber zu sprechen, ihn erneut zu erzählen ... aber hier ... der Lehrplan verlangt von ihnen tatsächlich, sie zu interpretieren, über Gefühle zu sprechen. Das sind zu hohe Ziele“. Lehrer A ist überzeugt, dass die sprachlichen Ziele und Richtlinien, gerade mit Blick auf „spontane Gespräche“, durchaus erreichbar sind. Als zu umfassend empfinden Lehrer B und D den Lernstoff, welchen die Schüler lernen und können sollen - ein mündlich geprägter Unterricht lässt sich dadurch nicht in dem Maße realisieren, wie es wünschenswert wäre, so ihre Aussage. Mit fachlich starken Schülern seien die Vorgaben erreichbar, aber nicht mit schwächeren Schülern, sagt Lehrkraft E: „Aber zu viel Zeit wird benötigt, um die Grundlagen zu erlernen, bevor wir mit dem beginnen, was Spaß macht“, das bedeutet aber auch, dass man nicht alle Kompetenzziele gleich intensiv behandeln kann: „Vieles ist nicht machbar, weil zu wenig Zeit ist, die neue Sprache zu lernen“, so Lehrer E.

\subsection{Herausforderungen bei der Bewertung der Schülerleistungen im mündlich- orientieren Unterricht}

Schüler in Norwegen haben Anspruch auf eine Bewertung ihrer mündlichen Leistung im Unterricht. Dies praktizieren die Lehrkräfte in der Stichprobe auch, in Form einer offiziellen Prüfung (,tentamen“). Häufig wird dabei über einen Text gesprochen, den die Schüler zuvor gelesen haben oder den sie präsentieren müssen. Neben der freien Rede sei ihr die Aussprache wichtig, sagte Lehrkraft A: „In erster Linie geht es darum, dass sie [die Schüler] verstanden werden und dass die Aussprache gut ist". Gute Aussprache und Intonation ist auch Lehrer D wichtig, ob Adjektive richtig gebeugt werden oder die Wortstellung des Gesagten richtig ist, seien hingegen in Niveaustufe I zweitrangig, so Lehrer D. Lehrer B setzt sich mit den Schülern vor der Prüfung zusammen und bespricht was bewertet werden soll: ,[...] wir [legen] gemeinsam Bewertungskriterien fest, wo man ein bisschen zusammen schaut, worauf ich achten soll.“ Wichtig ist allen Lehrern, dass nicht nur Texte wiederholt werden, sondern 
sich die Schüler auch eigene Gedanken zu einem Thema machen und versuchen, diese Gedanken in deutsche Worte zu fassen. Es müsse mehr kommen, als nur einige Stichworte, wenn ,... wir zum Beispiel über, Was ist typisch Deutsch“ reden, dann müssen sie mehr als nur ,Bier' und ,Auto' sagen, dann muss mehr kommen über das wir reden können noch ein wenig darüber hinausgehen, jetzt können wir über etwas mehr reden“, sagt Lehrer A. Neben diesen offiziellen mündlichen Prüfungen (,tentamen“) gibt es auch eine Reihe formlockerer Bewertungen (,underveisvurdering“) während der einzelnen Schulhalbjahre. In der Regel hören sich die Lehrer dabei Gruppengespräche an und bewerten neben Aussprache auch Argumentation und Spontaneität. Diese Art der Bewertung hat nach Ansicht von Lehrer C Vorteile, denn „es kann besonders für die Schüler eine gute Art der Bewertung sein, die sonst bei den Ganztagsprüfungen sehr nervös sind.“ Lehrer D sagt, dass für sie Vokabelwettbewerbe, Gruppengespräche und Frage-und-Antwort-Spiele zu den informellen Bewertungsmöglichkeiten gehören. Lehrer D versucht den Schülern dabei klar zu machen, dass es um eine positive Bewertung geht, ,ich versuche ihnen zu sagen, dass ich hören möchte, was sie können, nicht was sie nicht können. Je mehr Wörter sie verwenden können, desto mehr können sie kommunizieren. Das ist dann ein Plus“. Bei den offiziellen mündlichen Prüfungen beschreiben alle Lehrer ihre Schüler als häufig gestresst, die Schüler stehen unter Druck, weil sie geprüft werden. Um sie in einem eher natürlichen Gesprächsumfeld zu erleben und so ihre Fähigkeiten bewerten zu können, versuchen die Lehrer, eine weniger offizielle Atmosphäre zu schaffen. Neben spielerischen Mitteln greift Lehrer E auch zu einem Trick: "Ich habe den Eindruck, die Schüler denken, ich höre mit meinen Augen. Wenn ich also an einem Schreibtisch in der Nähe einer Gruppe sitze und jemanden anderen anschaue, dann sprechen sie relativ frei, das funktioniert sehr gut. [...] Sie erkennen nicht immer, dass sie beobachtet werden."

Aus Sicht von Lehrer E sind die Schüler dann wesentlich entspannter, als wenn die Lehrkraft offensichtlich mithört. Sie sprechen ohne Nervosität miteinander, auf eine positive Art und Weise, so Lehrer E. 


\section{Diskussion}

Verschiedene Theorien befassen sich mit dem Spracherwerb. In dieser Untersuchung wird der Spracherwerb ausdrücklich von der soziokulturellen Perspektive beleuchtet. Dieser theoretische Perspektive erscheint für diese Studie sinnvoll, da der in dieser Untersuchung untersuchte mündlich-kommunikative Unterricht eine starke soziale Komponente beinhaltet. Die soziokulturelle Sichtweise betrachtet Lernen als sozialen Prozess. Insbesondere der russische Psychologe Lev Vygotskij (1896-1934) hat zu dieser Sichtweise theoretisch beigetragen (vgl. Vygotskij, 1962) und auch Fachdidaktiker, wie beispielsweise Patsy Lightbown und Nina Spada (2013) erkennen die Bedeutung der gesprochenen Sprache für das Lernen im Allgemeinen und für das Erlernen einer Fremdsprache im Besonderen an. Auch im Lehrplan FSP1-01, dem die Lehrkräfte gesetzlich verpflichtet sind, hat der mündlichkommunikative Unterricht einen hohen Stellenwert, formuliert in den Zielen (,formål“), den grundlegenden Fertigkeiten (,grunnleggende ferdigheter") und Kompetenzzielen (,,kompetansemål“) (Utdanningsdirektoratet, 2006).

Die vorliegende Studie hatte als Ziel zu untersuchen, wie Lehrkräfte über den Anspruch eines mündlich geprägten und kommunikativen Unterrichts im Fach Deutsch denken und wie sie diesen Anspruch im Unterricht praktisch umsetzen. Im Folgenden werden die Befunde dieser Untersuchung diskutiert und in Beziehung zu theoretischen, empirischen und praktischen Überlegungen gesetzt (Abschnitt 6.1). Danach werden kurz methodische Überlegungen erläutert (Abschnitt 6.2) und anschließend die Relevanz dieser Arbeit diskutiert (Abschnitt 6.3).

\subsection{Befunde zum Verständnis und zur Umsetzung des mündlich-kommunikativen Unterrichts im Fach Deutsch}

Die Vorstellungen der Lehrkräfte darüber, wie man eine Sprache am besten Lernen kann, sind wichtig, denn diese wird ihre Gestaltung von Lernumgebungen beeinflussen (vgl. Helmke, 2014). In dieser Untersuchung waren sich alle Lehrkräfte einig, dass die mündliche Kommunikation ein zentraler und wichtiger Bestandteil beim Erwerb einer Fremdsprache ist. Somit scheinen alle Lehrkräfte die Richtlinien zu verstehen und mit dem Lehrplan und dessen mündlich-kommunikativer Ausrichtung einverstanden zu sein. Sie werten teilweise auch die 
mündlichen Fertigkeiten der Schüler als wichtiger als die schriftlichen Fertigkeiten und begründen dies damit, dass es wichtiger ist, in einer neuen Sprache mündlich kommunizieren zu können als korrekt zu schreiben. Die Anwendung der Sprache muss dabei auch nicht ganz korrekt sein, das Wichtige sei, dass überhaupt etwas gesagt wird. Dies stimmt überein mit Empfehlungen von Bjørke und Grønn (2018, S. 83), die hervorheben, dass die mündliche Sprache eine eigene Logik und eigene Regeln besitzt und dass daher einige Fachdidaktiker davon abraten, die Normen der Schriftsprache auf die mündliche Sprache zu übertragen, denn dies könnte dazu führen, dass die Schüler in ihrem Lernprozess gehemmt werden.

Theorien in die Praxis umzusetzen, wird oft als schwierig hervorgehoben (vgl. Imsen, 2016, S. 34). Daher war es interessant zu untersuchen, inwieweit die methodischen und fachdidaktischen Theoriegrundlagen den Lehrkräften bei der Wahl einer Methode im Unterricht helfen. Die Lehrkräfte der Stichprobe haben ihr Studium schon vor geraumer Zeit abgeschlossen und haben viele Jahre Schulerfahrung. Es ist deshalb nicht verwunderlich, dass ihnen die wissenschaftlichen Theorien nicht sehr präsent sind. Sie nennen zwar schlagwortartig Begriffe wie zum Beispiel das ,Didaktische Relationsmodell‘ („Didaktisk Relasjonsmodell“"), formuliert von Bjarne Bjørndal und Sigmund Lieberg (vgl. hierzu etwa Imsen, 2017, S. 303) und die ,Kognitive Meisterlehre` von Allan M. Collins, John S. Brown und Susan Newman (vgl. Reusser, 1995, S.175ff.), aber gehen nicht näher darauf ein. Laut Wahl (2001, S. 158 ff.) übernehmen mit der Zeit sogenannte subjektive Theorien bei den Lehrkräften eine sehr viel stärkere Rolle für das Handeln ein als wissenschaftliche Theorien. Subjektive Theorien sind Vorstellungen, die der Vorhersage und Erklärung von Handlungsweisen dienen, die aber nicht auf wissenschaftliche Art und Weise, sondern aus individuellen Überzeugungen entstanden sind. Im norwegischen Sprachraum hat sich eine parallele Theorie, die ,praktische Berufstheorie“ (,,praktisk yrkesteori“) von Per Lauvås und Gunnar Handal (Lauvås \& Handal, 2017, S. 28 ff.) etabliert, die mit dem Konzept „subjektive Theorien“" annähernd deckungsgleich ist. Beide Konzepte heben hervor, dass diese individuellen Überzeugungen in stärkerem Maße das didaktische Handeln der Lehrkräfte im Unterricht bestimmt als wissenschaftlich fundierte Theorien.

Möglicherweise kann der fehlende Theoriebezug auch darauf zurückzuführen sein, dass es an einer allumfassenden Theorie des Spracherwerbs einer zweiten Sprache fehlt (vgl. Lightbow \& Spada, 2017, S. 190). Der fehlende Theoriebezug bedeutet jedoch nicht, dass es 
an Vorstellungen guten mündlichen Unterrichts mangelt. Die Lehrkräfte heben die Nutzung variierter Unterrichtsmethoden, aktive mündliche Beteiligung der Lernenden, angenehmes Lernklima schaffen, Wiederholen von Inhalten, Phrasen lernen und Zeit zum Vorbereiten als zentrale Bedingungen für die mündliche Beteiligung im Unterricht hervor. Sie haben auch ein breites Repertoire an methodischen Vorgehensweisen, z.B. ,Speeddating', spontane Gespräche, Kreis-, Nachahm- und Rollenspiele (z.B. ein Besuch im Restaurant), Gesang, paarweises Lesen, mündliche Tests, sowie digitale Möglichkeiten. So gesehen scheinen die Lehrkräfte eher auf eine Werkzeugkiste mit einer Vielfalt an verschiedenen Unterrichtsmethoden zurückzugreifen, als sich Gedanken über aktuelle pädagogische und fachdidaktische Erkenntnisse und Ergebnisse zu machen. Die Elemente in dieser Werkzeugkiste mögen mehr oder weniger wissenschaftlich fundiert sein, das Wichtigste scheint aber, dass sie im Unterricht funktionell einsetzbar sind. All dies deutet daraufhin, dass im Alltag sicherlich Theorien implizit eine Rolle spielen, aber dass die subjektiven Theorien womöglich stärker präsent sind und das Lehrerhandeln steuern. Die Gefahr ist, dass diese subjektiven Theorien möglicherweise teilweise situativ funktionell sind, aber auf längere Sicht, etwa im Rahmen einer längerfristig anzulegenden Lernstrategie, in die Irre führen oder sich als nicht sinngemäßes Handeln festigen können (Helmke, 2004, S. 52), weil sie nicht wissenschaftlich erprobt sind. Möglicherweise kann es auch dazu kommen, dass die Unterrichtsmethoden in der „Werkzeugkiste“ nicht sinngemäß benutzt werden und somit ,am Ziel vorbei“" gehen.

Als Quellen der Inspiration für mündlichen Unterricht geben die Lehrer an, dass Sie durch Ausprobieren oder Notizen Unterrichtselemente wiederholen und verbessern können. Einige geben auch an, Netzwerke zu nutzen oder auf Kontakte an der Universität zurückgreifen. Ansonsten spielen didaktische Materialien wie Lehrbücher und Lernplattformen im Netz eine zentrale Rolle. Schließlich können auch Unterrichtsaktivitäten in anderen Fremdsprachen auf den Deutschunterricht übertragen werden. Viele der Lehrkräfte sehen ein gutes Lernklima in der Klasse als eine wichtige Voraussetzung für mündliche Beteiligung der Schüler im Unterricht. Obwohl dies sich auch theoretisch begründen lässt, zum Beispiel mit der Selbstbestimmungstheorie von Deci \& Ryan (1993), die die Bedeutung des sozialen Kontextes für das Lernen (neben Autonomie- und Kompetenzunterstützung) als ein angeborenes Grundbedürfnis für selbstbestimmtes und motiviertes Lernen betrachtet, 
scheinen diese Überzeugungen eher auf Erfahrungen und auferlegten Richtlinien zu beruhen als auf einem theoretischen Verständnis dafür, was dies konkret für das Lernen bedeutet.

Herausforderungen bei der Umsetzung der mündlichen Aktivitäten im Unterricht nennen die Lehrkräfte häufig. Die Schule ist ein Spiegelbild der Gesellschaft und die Schüler verfügen über unterschiedliche soziale und kulturelle Erfahrungen (vgl. Imsen, 2018, S. 245). Unabhängig davon, ob es um die Jugendschule oder die weiterführende Schule geht, werden für die Lehrer das soziale Umfeld, die Probleme und Herausforderungen aber auch allgemeine gesellschaftliche Entwicklungen in der Schule und im Unterricht sichtbar.

Die unterschiedlichen Leistungsniveaus der Schüler sind seit jeher eine Herausforderung für Lehrer (vgl. Imsen, 2018, S. 245). Die Leistungsheterogenität der Schüler führt dazu, dass von Seiten der Lehrer weniger Deutsch gesprochen wird. Sie wollen damit sichergehen, dass die Inhalte ihres Unterrichts von allen Schülern, insbesondere den fachlich schwächsten Schülern, verstanden werden. Der Anspruch, dass die Schüler sich bestimmte grammatikalische Grundlagen vor dem Übergang von der Jugend- in die weiterführende Schule aneignen müssen, führe zu einem erhöhten Fokus auf das Schriftliche, so die Lehrkräfte. Als besondere Herausforderung im Fach Deutsch wird die geringe Auseinandersetzung mit der Sprache im Alltag und die knapp bemessende Unterrichtszeit genannt. Es werden vergleichsweise wenige Unterrichtsstunden unterrichtet und die Schüler begegnen der Sprache Deutsch seltener im Alltag (beispielsweise im Fernsehen, Kino, in Computerspielen), als es bei der englischen Sprache der Fall ist. Somit ist es im Vergleich zum Englischen schwieriger, einen deutschen Wortschatz aufzubauen und die Strukturen der Sprache zu verstehen. Auch der Lernstoff wird als sehr umfassend empfunden, so dass bei den Lernzielen notgedrungen Prioritäten gesetzt werden müssen, die u. U. vom Lehrplan in dieser Form nicht vorgesehen sind. Insofern kann es sein, dass Lerninhalte unterschiedlich intensiv durchgenommen werden und dass dies zu Lasten des mündlichen Anteils im Unterricht gehen kann. Dies würde dann dieselbe Problematik widerspiegeln, die beispielsweise in der DESI-Videostudie von Helmke et al. (2008) aufgedeckt wurde, nämlich, dass der gesprochene Anteil der Fremdsprache (in diesem Falle Englisch) im Unterricht verhältnismäßig niedrig ist und nicht eine zentrale Rolle hat wie im norwegischen Lehrplan erwünscht. 
Schüler in Norwegen haben Anspruch auf eine Bewertung ihrer Leistung im Unterricht (Opplæringsloven, 2017, §3-1). Eine wichtige Voraussetzung, die mündlichen Leistungen der Schüler beurteilen zu können, ist, dass es Gelegenheiten für Beurteilungen überhaupt gibt. Gibt es für die Schüler nur wenige Möglichkeiten ihre sprachlichen Fähigkeiten mündlich zu präsentieren, dann gibt es ebenfalls nur wenige Bewertungsmöglichkeiten. Somit stellt sich die Frage, nach welchen Kriterien und Ansprüchen die Lehrkräfte dann Noten für die mündliche Mitarbeit der Lernenden vergeben. Die Lehrkräfte berichten von formellen und informellen Bewertungssituationen der Schüler, aber auch von Zwischenbewertungen (,underveisvurdering“) und Prüfungen (,sluttvurdering“). Die interviewten Lehrkräfte führen sowohl mündliche formative „unterwegs“-Beurteilungen als auch summative „End“-Bewertungen durch. Die summative Abschlussprüfung wird in der Regel als terminlich festgesetzte Prüfung durchgeführt, die vom Lehrer mit dem Schüler einzeln in Form eines Prüfungsgesprächs geführt wird. Häufig wird über einen Text gesprochen, den der Schüler bzw. Schülerinnen zuvor gelesen hat oder den er bzw. sie präsentieren muss. Die „unterwegs“-Beurteilung der mündlichen Fähigkeiten der Schülerinnen und Schüler im Unterricht birgt hingegen einige Schwierigkeiten und fordert besonderes Feingefühl der Lehrer. Die Beurteilung von schüchternen und zurückhaltenden Schülern ist nach Aussagen der Lehrer dabei eine besondere Herausforderung. Das gelinge häufig nur, wenn sich diese Schüler unbeobachtet fühlen, so die Lehrer. Unter anderem beobachten sie diese Schüler dann, wie sie bei Gruppenaufgaben mit anderen Schülern sprechen. Weitere Möglichkeiten sind von den Schülern selbstgedrehte Filme mit Kommentaren oder selbstproduzierte Audiofiles. Die Lehrer achten dabei auf die Aussprache, die Intonation, den Wortschatz, die Wortstellung und den richtigen Gebrauch von Adjektivdeklinationen und Präpositionen. Eine wichtige Rolle auch bei der Beurteilung der mündlichen Schülerleistungen spielt die Vorbereitung des Stoffs und das Lernklima in der Klasse.

\section{2 Überlegung zur methodischen Umsetzung der Untersuchung}

Als Methode zur Datenerhebung wurde für diese Untersuchung die Form eines semistrukturierten Interviews gewählt. Bei einem Interview entsteht eine Situation, die einem Gespräch sehr nahekommt und häufig einen offenen, fast persönlichen Charakter erreicht 
(Postholm \& Jacobsen, 2017, S. 68). Diese Untersuchung hatte als Ziel, Auffassungen und Meinungen der Lehrkräfte zu erfassen. „Subjektive Bedeutungen lassen sich nur schwer aus Beobachtungen ableiten. Man muss hier die Subjekte selbst zur Sprache kommen lassen" so Philipp Mayring (2002, S. 66). Daher wurde die Form des semistrukturierten Interviews gewählt. Die semistrukturierte Interviewform lässt einerseits den Befragten die Freiheit, mit seinen eigenen Worten auf die gestellte Frage zu antworten, andererseits hat der Forscher die Möglichkeit Nachfragen zu stellen („,oppfølgingsspørsmål“) (Postholm \& Jacobsen, 2017, S. 75). Dies erwies sich in dieser Studie als großer Vorteil. Die befragten Lehrer antworteten unterschiedlich ausführlich auf die Fragen, so dass die Möglichkeit der Nachfrage einzelne Lehrer dazu brachte, zusätzliche Informationen zu geben. Durch Nachfragen war es auch möglich, zunächst recht allgemeine Antworten zu präzisieren. Allerdings zeigte sich auch, dass gutes Fragen geübt sein will, so schlich sich doch die eine oder andere ungewollte suggestive Nachfrage ein, die daher leider in der Auswertung keine Beachtung finden konnten. Interviewt wurden fünf Lehrer, beiderlei Geschlechts, von fünf Jugend- und weiterführenden Schulen der Region Agder. Die Studie kann aufgrund des geringen Stichprobenumfangs nicht als repräsentativ eingestuft werden, dazu hätte die Informantenauswahl deutlich größer und regional weiter gefasst sein müssen. Eine Vertiefung der Problemstellung und eine größere Stichprobe wären möglicherweise für eine ausführliche Studie im Rahmen einer Master- oder Doktorarbeit interessant.

\subsection{Relevanz der Arbeit}

Ausgangspunkt für diese Untersuchung war die zunächst eher zufällige Beobachtung, dass im Deutschunterricht in Norwegen relativ wenig Deutsch gesprochen wird - von Lehrern und von Schülern gleichermaßen. Gestützt wurde diese Annahme vor allem durch Befunde aus einer bekannten DESI-Videostudie über Fremdsprachenunterricht im Fach English in Deutschland (Helmke, 2004), wobei sich natürlich die Frage nach der Übertragbarkeit der DESI-Befunde auf den Deutschunterricht in Norwegen stellt, da hierzu keine entsprechenden Studien vorliegen.

Der Lehrplan für Fremdsprachen FSP1-01 (Utdanningsdirektoratet, 2006) verlangt in seinen Richtlinien ein hohes Maß an mündlicher Kommunikation in der Zielsprache. Die vorliegende Untersuchung zeigt, dass den Lehrkräften bewusst ist, dass ein hoher Anteil des 
Deutschunterrichts mündlich erfolgen soll. Alle Lehrer zeigen auch Einsatz, Initiative und Fantasie, um diesem Ziel, das in den Richtlinien des Lehrplans formuliert ist, nachzukommen. Doch durch die Interviews mit den Lehrkräften wird auch deutlich, dass heterogene Klassenstrukturen, die hohe Zahl unterschiedlicher und anspruchsvoller Kompetenzziele, Motivationsprobleme bei den Schülern und eine knapp bemessene Stundenzahl für das Fach, einen mündlich geprägten Fremdsprachenunterricht schwierig machen. Um diese Schwierigkeiten zu bewältigen, haben sich alle Lehrer ein Repertoire an unterschiedlichen Werkzeugen angeeignet. Dieser methodische „Werkzeugkasten“ wird aus Sicht der Lehrkräfte durch die weitere Digitalisierung des Unterrichts und Vernetzung der Lehrer auch weiter gefüllt. So können die Lehrer voneinander profitieren. Gleiches gilt auch für die unterschiedlichen Vorgehensweisen bei der Leistungsbewertung der Schüler. Diese Erfahrungen dürften gerade bei neuen Lehrern auf Interesse stoßen, die sich noch orientieren und noch kein so großes Repertoire an Handlungsmustern haben.

Das Erlernen von Fremdsprachen neben Englisch genießt in Norwegen auch weiterhin einen hohen Stellenwert. Dies wird auch in den Entwürfen zum neuen Lehrplan „Fagfornyelsen 2020“ sichtbar. Dort werden die mündlichen Fertigkeiten an erster Stelle der insgesamt vier Grundfertigkeiten im Fremdsprachenfach genannt (vgl.

Utdanningsdirektoratet, 2019, S. 4). Von den fünf, die Kommunikation betreffenden Punkten in den Kompetenzziel der Niveaustufen I und II, beschreiben die ersten Punkte mündliche Kompetenzziele (vgl. Utdanningsdirektoratet, 2019, S. 5ff.). Nicht zuletzt wird bei der Endnotenbewertung der Schüler darauf hingewiesen, dass schriftliche und mündliche Kompetenzen gleich gewichtet werden sollen (Utdanningsdirektoratet, 2019, S. 6 ff.). Damit wird auch im neuen Lehrplan der mündlich-kommunikative Unterricht einen hohen Stellenwert haben.

\section{Literatur}

Bjørke, C., \& Grønn, B., (2018). Muntlige ferdigheter. In: C. Bjørke, M. Dypedahl, \& A. Haukås (Hrsg.). Fremmedspråksdidaktikk (2. Auflage, S. 80-95). Oslo: Cappelen Damm Akademisk.

Bjørke, C., Dypedahl, M., Haukås, Å. (2018). Fremmedspråksdidaktikk. Oslo: Cappelen Damm Akademisk. 
Deci, E. L., Ryan, R. M. (1993). Die Selbstbestimmungstheorie der Motivation und ihre Bedeutung für die Pädagogik. Zeitschrift für Pädagogik 39(2), 223-238.

Europarat (2001). Gemeinsamer Europäischer Referenzrahmen für Sprachen. Heruntergeladen am 29.4.2019 von http://www.europaeischer-referenzrahmen.de/.

Heimark, G. E. (2007). Fagdidaktikk og fremmedspråksdidaktikk. Et fors $\varnothing \mathrm{k}$ på å plassere 2. fremmedspråk i et fagdidaktisk perspektiv. Acta Didactica Norge 1(1). 1-15. https://doi.org/10.5617/adno.4777.

Helmke, A. (2004). Unterrichtsqualität. Erfassen-Bewerten-Beurteilen. Seelze: Kallmeyer.

Helmke T., Helmke A., Schrader, F.-W., Wagner, W., Nold, G., Schröder, K. (2008) Die Videostudie des Englischunterrichts. In: DESI-Konsortium (Hrsg.), Unterricht und Kompetenzerwerb zu Deutsch und Englisch. DESI-Studie: Die Ergebnisse, Leistungsverteilung und Bedingungsfaktoren (S. 345-363). Weinheim: Beltz.

Imsen, G. (2014). Elevens verden. Innføring i pedagogisk psykologi. Oslo: Universitetsforlaget.

Imsen, G. (2016). Laererens verden. Innfфring i generell didaktikk. Oslo: Universitetsforlaget. Kirke- og undervisningsdepartementet (1939). Normalplan for byfolkeskolen (N39). Heruntergeladen am 29.4.2019 von https://www.nb.no/nbsok/nb/a772fcd5e1bbbfb3dcb3b7e43d6ccc60?lang=no\#0.

Kirke- og undervisningsdepartementet (1974). Mønsterplan for grunnskolen (M74). heruntergeladen am 29.4.2019 von https://www.nb.no/nbsok/nb/27717cffb91e04bca5ed6b5f90ec1034?lang=no\#0.

Kirke- og undervisningsdepartementet (1987). Mфnsterplan for grunnskolen (M87). heruntergeladen am 5.5.2019 von https://www.nb.no/nbsok/nb/2aef891325a059851965d5b8ac193de5\#3.

Kleinschmidt-Schinke, K. (2018). Die an die Schüler/-innen gerichtete Sprache (SgS). Berlin: de Gruyter.

Kunnskapsdepartementet (2007). Strategi for styrking av fremmedspråk i grunnopplaringen 2005-2009, revidert 2007. Heruntergeladen am 29.4.2019 von https://www.fremmedspraksenteret.no/neted/upload/attachment/site/group55/UDIR_Spra kApnerDorer_07nett.pdf.

Lightbown, P., Spada N. (2013). How Languages are Learned. (4. Aufl.). Oxford: University Press. https://play.google.com/books/reader?id=5PadBgAAQBAJ\&pg=GBS.PP1.

Mayring, P. (2010) Qualitative Content Analysis. In: U. Flick, E. von Kardoff \& I. Steinke (Hrsg.). A Companion to Qualitative Research (S. 266-269). London: Sage.

Mayring, P. (2002) Einführung in die Qualitative Sozialforschung (5. Aufl.). Weinheim: Beltz.

Moen, T. (2013). Sosiokulturell teori. Vygotsky i teori og praksis. In: Karlsdottir, R. \& Hybertsen Lysø, I. (Hrsg.). Laring - Utvikling - Laeringsmiljø. En innføring i pedagogisk psykologi (S. 251-265). Trondheim: Akademika.

Opplæringsloven (1998, endring 9. Juni 2017). Lov om grunnskolen og den vidaregåande opplacinga (LOV-1998-07-17-61). Heruntergeladen am 26.4.2019 von https://lovdata.no/lov/1998-07-17-61.

Postholm, M.B. (2010). Kvalitativ metode. En innføring med fokus på fenomenologi, etnografi og kasusstudier. Oslo: Universitetsforlaget.

Postholm, M.B., Jacobsen, D.I. (2017). Lareren med Forskerblikk. Innfфring i vitenskapelig metode for larerstudenter (8. Aufl.). Oslo: Cappelen Damm Akademisk. 
Reusser, K. (1995). Lehr-Lernkultur im Wandel: Zur Neuorientierung in der kognitiven Lernforschung. In: R. Dubs \& R. Dörig (Hrsg.). Dialog Wissenschaft und Praxis. Berufsbildungstage St. Gallen (S. 164-190). St. Gallen: Institut für Wirtschaftspädagogik IWP.

Säljö, R. (2013). Støtte til læring-tradisjoner og perspektiver. In: R. Säljö, \& R. J. Krumsvik (Hrsg.). Praktisk- pedagogisk utdanning (S. 53-79). Bergen: Bokforlaget.

Tornberg, U. (2015). Språkdidaktik. Malmö: Gleerups.

Trebbi, T. (2005). Det andre fremmedspråket: Fra elitefag til et fag for alle? In: K. Børhaug, A.-B. Fenner, \& L. Åse (Hrsg.). Fagenes begrunnelse (S. 103-113), Bergen: Fagbokforlaget.

Utdanningsdirektoratet. (2019). Laereplan i fremmedspråk (høringsdokument 18. mars 2019). heruntergeladen am 29.4.2019 von https://hoering.udir.no/Hoering/v2/340?notatId=699.

Utdanningsdirektoratet. (2006). Lareplan i fremmedspråk (FSP1-01).

Utdanning- og forskningsdepartementet (2006). Kunnskapsløftet (LK06). Heruntergeladen am 29.4.2019 von

https://www.uio.no/studier/emner/hf/ilos/FRA4109/v06/Laereplaner06FRA4109hjemmee ksamenV06.pdf.

Vygotskij, L., Hanfmann, E., \& Vakar, G., (1962). Thought and Language. Cambridge, Mass: M.I.T.

Wahl, D. (2001). Nachhaltige Wege vom Wissen zum Handeln. In: Beiträge zur Lehrerinnenund Lehrerbildung 19(2), 157-174. 
Nordic Journal of Modern Language Methodology

\section{Anhang}

Anhang A: Interviewleitfaden

\begin{tabular}{|c|c|}
\hline Forschungsfragen & Fragen \\
\hline $\begin{array}{l}\text { 1. Wie verstehen die Lehrkräfte die Richtlinien im } \\
\text { Lehrplan für Fremdsprachen FSP1-01 in Bezug auf } \\
\text { mündlich geprägten Unterricht? }\end{array}$ & $\begin{array}{l}\text { A. Warum ist deiner Ansicht nach ein mündlicher, } \\
\text { kommunikativer Fremdsprachenunterricht wichtig? } \\
\text { B. Wie verstehst du die Richtlinien im FSP1-01 in } \\
\text { Bezug auf mündlichen Unterricht? } \\
\text { C. Sind die Richtlinien im FSP1-01 in Bezug auf einen } \\
\text { mündlich geprägten Unterricht deutlich genug? } \\
\text { Wieso/Wieso nicht? }\end{array}$ \\
\hline $\begin{array}{l}\text { 2. Wie setzen die Lehrkräfte die Richtlinien } \\
\text { bezüglich der mündlichen Beteiligung im Unterricht } \\
\text { methodisch und fachdidaktisch um? }\end{array}$ & $\begin{array}{l}\text { A. Wie gestaltest du deinen mündlich-geprägten } \\
\text { Unterricht? } \\
\text { B. Wie gehst du methodisch und fachdidaktisch vor? } \\
\text { C. Was funktioniert/ funktioniert nicht? }\end{array}$ \\
\hline $\begin{array}{l}\text { 3. Welche Herausforderungen sehen die Lehrkräfte } \\
\text { bei der Umsetzung bezüglich der Richtlinien, einen } \\
\text { mündlich-geprägten Unterricht zu gestalten? }\end{array}$ & $\begin{array}{l}\text { A. Wo siehst du die größten Herausforderungen bei } \\
\text { der Umsetzung eines mündlich-geprägten } \\
\text { Unterrichts? } \\
\text { B. Sind die Richtlinien, die für einen mündlich- } \\
\text { geprägten Unterricht aufgestellt sind, realistisch oder } \\
\text { unrealistisch? Wieso/Wieso nicht? }\end{array}$ \\
\hline $\begin{array}{l}\text { 4. Welche Herausforderungen sehen die Lehrkräfte } \\
\text { bei der Umsetzung bezüglich der Richtlinien, die } \\
\text { Leistungen der Schüler in einen mündlich-geprägten } \\
\text { Unterricht zu bewerten? }\end{array}$ & $\begin{array}{l}\text { A. Wie (nach welchen Kriterien) bewertest du die } \\
\text { mündliche Beteiligung deiner Schüler/innen? }\end{array}$ \\
\hline
\end{tabular}


Nordic Journal of Modern Language Methodology

Anhang B: Rohdaten und Analysestruktur

\begin{tabular}{|c|c|c|c|c|}
\hline & & $\begin{array}{c}\text { Lehrer A, Lehrer B, Lehrer C, Lehrer D, } \\
\text { Lehrer E }\end{array}$ & Analyse & $\begin{array}{c}\text { Diskussion/Bezug zur } \\
\text { Theorie }\end{array}$ \\
\hline \multirow[t]{2}{*}{$\begin{array}{l}\text { Forschu } \\
\text { ngs- } \\
\text { frage } 1\end{array}$} & F1-1 & $\begin{array}{l}\text { Lehrer A: Jeg tenker der er viktig for det } \\
\text { handler ja om språk og språk handler jo } \\
\text { om å snakke sammen, om å forstå } \\
\text { hverandre, om å kommunisere med } \\
\text { hverandre. Det er litt av poenget med å } \\
\text { lære et nytt språk, , tenker jeg. ja. } \\
\text {-------------------------- } \\
\text { Lehrer B: Ja jeg synes jo det er det } \\
\text { viktigste i språket, for det skal kunne } \\
\text { brukes - det skal kunne anvendes. Sånn at } \\
\text { jo mer muntlig du klarer å gjøre det, jo } \\
\text { mer kan en anvende det. Hvis en kommer } \\
\text { til spesielt i sånne fremmedspråk som en } \\
\text { har, som tysk, så legger jeg mye vekt på } \\
\text { det - mer og mer. } \\
\text { L----------------------------- } \\
\text { Lehrer C: Jeg tenker det er viktig spesielt } \\
\text { nå som det er så mye } \\
\text { oversettelsesprogram og en skal kunne } \\
\text { kommunisere, så er det viktig og å kunne } \\
\text { også snakke person til person og ikke bare } \\
\text { sitte å oversette på et } \\
\text { oversettelsesprogram. Så derfor er det } \\
\text { viktig i timene og ha muntlig } \\
\text { kommunikasjon og } \emptyset \text { ve seg i et klasserom } \\
\text { for senere å kunne bruke det i livet. } \\
- \text { Le----------------- } \\
\text { Lehrer D: Kommunikasjon er jo viktig, det } \\
\text { er jo liksom hovedfokus nesten hvorfor } \\
\text { man kanskje skal lære et fremmedspråk i } \\
\text { første omgang. Og det å kunne prate med } \\
\text { mennesker... det er kanskje det de fleste } \\
\text { vil omgås, eh... ikke nødvendigvis skrive } \\
\text { fremmedspråk så-så det å kunne prate } \\
\text { målspråket det er - det er viktig. Ja. } \\
- \text { Lehrer E: Hvorfor muntlig kommunikativ } \\
\text { fremmedspråkundervisning er viktig? For } \\
\text { det er jo et språk, så enkelt er det! Skal du } \\
\text { lære deg et språk, så kan du ikke bare lære } \\
\text { det skriftlig. Du skal lære deg å } \\
\text { kommunisere, du skal lære å } \\
\text { kommunisere skriftlig og muntlig. Når jeg } \\
\text { skal lære et språk så må jeg kunne snakke } \\
\text { det det er jo egentlig veldig enkelt syns } \\
\text { jeg. }\end{array}$ & $\begin{array}{l}\text { Sprache als ein Mittel, um miteinander } \\
\text { kommunizieren zu können. Jetzt } \\
\text { kommunizieren, um es später im Leben } \\
\text { nutzen zu können. Das Sprechen in der } \\
\text { Wertigkeit fast wichtiger als das } \\
\text { Schreiben, weil man in erster Linie } \\
\text { meistens sprechen gebrauchen kann }\end{array}$ & $\begin{array}{l}\text { Soziokulturelle } \\
\text { Perspektive, Vygotskys } \\
\text { Theorie geht davon aus, } \\
\text { dass kognitive } \\
\text { Entwicklung, auch die } \\
\text { Sprachentwicklung, als } \\
\text { ein Ergebnis sozialer } \\
\text { Interaktionen entsteht } \\
\text { (Lightbow \& } \\
\text { Spada,2006, s47). Ganz } \\
\text { zentral dabei sind die } \\
\text { Interaktionen zwischen } \\
\text { Individuen. Das } \\
\text { Sprechen und das } \\
\text { Denken sind dabei } \\
\text { verwobene Prozesse. }\end{array}$ \\
\hline & F1-2 & $\begin{array}{l}\text { Lehrer A: Ja altså, nå vet jeg ikke om jeg } \\
\text { forstår deg riktig, men det er mange } \\
\text { kompetansemål som går direkte på nemlig } \\
\text { på spontan samtale, det at en reagerer, at } \\
\text { en forstår hverandre, at en tilpasser } \\
\text { språket i forhold til en samtale da, men }\end{array}$ & $\begin{array}{l}\text { Die Richtlinien sind nicht unbedingt ins } \\
\text { Detail bekannt, aber im Wesentlichen } \\
\text { können die LK Auszüge aus den } \\
\text { Richtlinien benennen, die auf einen } \\
\text { mündlich geprägten Unterricht zielen. } \\
\text { Lehrkraft A hebt „spontane Gespräche“ } \\
\text { und "Alltagsbezüge" hervor. }\end{array}$ & \\
\hline
\end{tabular}


Nordic Journal of Modern Language Methodology

2019, 7 (1), 116-165 (Part B - Not peer reviewed)

vet ikke om jeg forsto det helt... Ekstrafrage: Joda. Men synes du det er tydelig nok forklart det som du skal gjøre med elevene? Det er jo ikke veldig konkret men det er jo - altså dette med delta i spontane samtaler om ulike tema og aktuelle emner - altså spontane samtaler er jo konkret, men det står ikke akkurat om hvilke, om hva slags, tema så der står vi jo litt fritt men det tenker jeg jo er litt fint også, at en kan bruke det som skjer i hverdagen, det som skjer altså når en kommer inn i timen så kan en fortelle hva som skjedde på veien, ikke sant - litt sånne ting. Extrafrage: Hvis du hadde hatt mulighet, hvordan ville du utvidet retningslinjene, Synes du det hadde vært greit om det hadde vært vært mer konkret? På hvilken måte? Kanskje du har et eksempel? I forhold til altså å endre kompetansemål, tenker du på? Jeg liker litt friheten, jeg. At det ikke det for, at jeg må følge sånn veldig spesiell plan for oppnå alt, men at jeg står litt fritt men det er klart at... de kunne jo også gitt eksempler på aktuelle emner... er det i media i Tysland eller handler det mer om kultur...ja, absolutt.

Lehrer B: Jeg synes på ungdomsskolen så gjør de det. Men jeg vet at når jeg sender elever videre til videregående så blir jeg nødt til å gnave mye på grammatikk for det de får så mye av det i videregående. Så jeg hadde håpet at det kunne vært enda mer muntlig og at man hadde lagt ned alt det skriftlige i mye st $\varnothing$ rre grad og holdt på mye mer med muntlige øvelser, ja. Det gjør det, det ligger innforbi du skal ha en del muntlig stoff da.

Lehrer C: Både det at det står at du skal forstå muntlige tekster, du skal både lese og forstå og tolke teksten. Det står mye om at du skal ha spontane samtaler, du skal også prøve å uttrykke følelser altså emosjoner og opplevelser som du skal fortelle om. Og det står at du skal ha tverrfaglige emner, at man kan snakke om forskjellige temaer. Så det står det ganske mye om og det skal jo telle ca $50 \%$ det. Ekstraspörsmül: Synes du at disse retningslinjene er tydelig nok? Ja, det synes jeg de er. Extrafrage: Har du tenkt om på hvilken måte du kan utvide det me tanke på den nye læreplanen? Nei jeg har faktisk ikke tenkt så mye akkurat det og jeg har ikke satt meg helt inn enda i den nye læreplanen, hvordan det blir da, men jeg vil faktisk heller ha det mer konkret at man kan ja..at det står enda mer hva... at jeg synes det er åpent nok. Så hvis det blir mer åpent så er ikke jeg enig i det.

Lehrer D: Hvis en tenker på at den er jo delt opp i liksom dette her som heter
Lehrkraft B pointiert, dass trotz mündlichem Fokus viel Grammatik gemacht werden muss, um die Schüler auf die weiterführende Schule vorzubereiten.

Lehrkraft C weißt konkret auf sowohl "das Lesen, Verstehen und Interpretieren von Texten" als auch auf "spontane Gespräche“, „Emotionen ausdrücken“ und „fächer- und themenübergreifende Inhalte" hin. Sie hebt insbesondere den hohen Stellenwert des mündlichen Anteils im Unterricht hervor. Lehrkraft D fokussiert auf "Sprache“, „Kultur" \& "Gesellschaft". Lehrkraft E verhält sich lediglich zu den Kompetenzzielen, weißt aber auch auf die mündlichen Aspekte dieser hin.

Die Lehrkräfte stimmen überein, dass die Kompetenzziele nicht sonderlich konkret sind, aber sie divergieren in ihren Auffassungen, inwieweit sie dies gut finden.

Lehrkraft A findet es gut, dass die Richtlinien Raum für Flexibilität lassen Lehrer $\mathrm{C}$ fände es hilfreich, wenn sie noch konkreter wären.

Einige Lehrkräfte $(C$ und $D)$ sind gespannt, Lehrkraft $C$ jedoch auch skeptisch, inwieweit die neuen Richtlinien, die im Herbst 2020 in Kraft treten, gute Änderungen herbeiführen. 
Nordic Journal of Modern Language Methodology

2019, 7 (1), 116-165 (Part B - Not peer reviewed)

kommunikasjon, språk, kultur, samfunn og også språklæring så vil jeg jo si at det som heter kommunikasjon da, innafor det av de tre inndelingene der, men så er det jo noe med det at du jo også skal kunne kommunisere i forhold til det som heter "språk, kultur og samfunn". Språklæring... kanskje ikke så mye, men inni språklæring er det jo også det at du skal jo lære deg, holdt jeg på å si, fraser som er typiske i tyske målområder da. Extrafrage: Er det tydelig nok? Nei, de er litt vage. Jeg synes det. Men jeg vet jo samtidig at de fokuserer veldig på at de skal bli tydeligere $\mathrm{da}$, i den nye læreplanen som kommer. Extrafrage: Hvordan kunne det etter din mening utvides? Hvordan jeg ville gjort det? Det er litt sånn vanskelig også tenke det nå for nå har en jo lest en del om den nye planen, så da er du litt farget av det. Men jeg syns jo det er en god ide da, at det skal være mer fokus på muntlig kommunikasjon. Så er også det med intonasjon det er ikke vektlagt så mye i den nye for eksempel og det er kanskje litt smart. Litt trist eh at en ikke skal behøve å ha sangen for eksempel i det tyske språket, men samtidig så vil det være mindre skummelt da, så ja.

Lehrer E: Hvis vi går på

kompetansemålene, for vi har jo de generelle kompetansemålene, der står det jo i forhold til.. jeg forholder meg til kompetansemålene, til enhver tid, det er det som er grunnlaget for undervisningen min, så har du de generelle

kompetansemålene, der står det jo listet opp eller der står det i forhold at de skal kunne snakke. De skal ha skriftlig, de skal ha muntlig de skal ha kommunikasjon mhp eller jobbe ift til data og der går vi inn på den muntlige jobben også har vi jo nå jobber nå jeg på nivå 1 kun, og der er det vel fire eller fem kompetansemål- nå har jeg det ikke i hodet akkurat- men det er vel en fjerdedel eller en femtedel av kompetansemålene som går på det muntlige, og det forholder jeg meg til. Og det er jo egentlig kompetansemålene som jeg mener at er retningslinjene mine. Extrafrage: Er det tydelige nok? Det står at de skal kunne kommunisere en enkel samtale, de skal kunne presentere, så det står jo veldig punktvis. Akkurat de muntlige kompetansemålene synes jeg egentlig er de er jo veldig generelle for de skal jo inngå i ulike språk, de skal jo ikke bare være tysk, spansk og fransk det skal inngå også dem som tar kinesisk som privatist, eller Thailand, eller arabisk eller persisk så det er jo veldig generelt på den måten. Så blir det jo tilpasset ift konkretisert i faget gjennom den jobben jeg som lærer gjør, tenker jeg. 
Nordic Journal of Modern Language Methodology

Lehrer A: Jeg vet ikke om jeg burde ha forberedt meg litt bedre på den - om jeg burde ha lest den bedre? Står det masse mer i forhold til eller utover dette? ... Ja, altså i forhold til min undervisning så legger jeg opp sånn at vi vet hver time at alle må prater i hver time. Jeg må - altså . Jeg begynner på tysk og prater, planen for timen og så videre, og så må alle elevene snakke to og to eller tre og tre, fire og fire. Alle må snakke en gang i timen - høyt - det er jo en fare alltid at det blir for mye skriftlig, så det det er jo veldig viktig, tenker jeg, at alle må prate, - at det ikke er noen som bare kan sitte og ikke si noen ting - og da må en ofte hjelpe lite granne i gang. Fordi at de det er jo... de sliter med ordforrådet, ehm og da gjør jeg det ofte sånn for eksempel at vi har en tema at de får lage tankekart for eksempel først, de kan bruke ordnett pluss, og så at de ut fra tankekartet snakker med hverandre to og to eller at jeg gir dem noen spørsmål gir dem en gul lapp hvor de får lov til å forberede et lite tema så kan de snakke to og to, så kan jeg bytte rundt på folk.... og så prøver jeg ofte å ha en oppsummering hvor alle må si kort eller en bare den ene raden .. eller alle i klassen - det kommer an på hvor mange det er i klassen, Hvis det er 30 så kan det ta litt tid...Jeg prøver å... jeg prøver invertfall å variere det, sånn at de får muligheten til å prate, men også av og til at de får muligheten til å forberede seg bitte litt, altså å slå opp noen ord hvis de mangler mange ord, og jeg hjelper litt i gang med noen spørsmål hvis de sliter med det også. Så sier jeg veldig ofte at "det skal være en samtale det er ikke noe intervju, du må komme med "echt?", "wieso?", "wie spannend!" altså sånn at det blir sånn litt oppfølgingsspørsmål at begge to har ansvar for å holde samtalen i gang. At det ikke bare sånn at den ene stiller spørsmål den andre må også stille spørsmål, og de må svare og være interessert.

Lehrer B: Med tanke på.. så sier jo læreplanen noe om at du skal - ikke santkunne anvende språk, det sier noe om at du skal lære litt om tysk kultur - ikke sant du skal lære - kunne kommunisere via veil.... nå kommer det snart en ny læreplan så jeg vet jo ikke hvordan den blir revidert da men, men foreløpig så...snakker man jo mye om muntlig kommunikasjon. Extrafrage: Hvis du hadde mulighet - stikkord fagfornyelsen hvordan ville du ha utvidet retningslinje? Ja jeg synes jo at i den nye læreplanen burde det være større fokus på muntlig og mindre fokus på det skriftlige for det er det som vil være aktuelt for folk å bruke når de skal lære dette språket egentlig, så
Alle müssen im Laufe der Stunde laut reden (A), in Paaren oder Gruppen Lehrkraft startet die Stunde auf Deutsch, Plan und Ziele der Stunde A. Mind-map und "Ordnett Pluss" um den Wortschatz aufzustocken A. Ein Thema anhand von zugeteilten Fragen auf einem gelben Zettel beantworten $\mathrm{A}$

Aufsummieren, alle oder der Reihe nach Gespräche führen A, E

Lesen und die Aussprache üben $C, E$ Struktur der Sprache verstehen D Sich über ein aktuelles Thema unterhalten $\mathrm{C}$

Mündlich präsentieren $\mathrm{E}$ 
Nordic Journal of Modern Language Methodology

2019, 7 (1), 116-165 (Part B - Not peer reviewed)

\begin{tabular}{|c|c|c|c|c|}
\hline & & 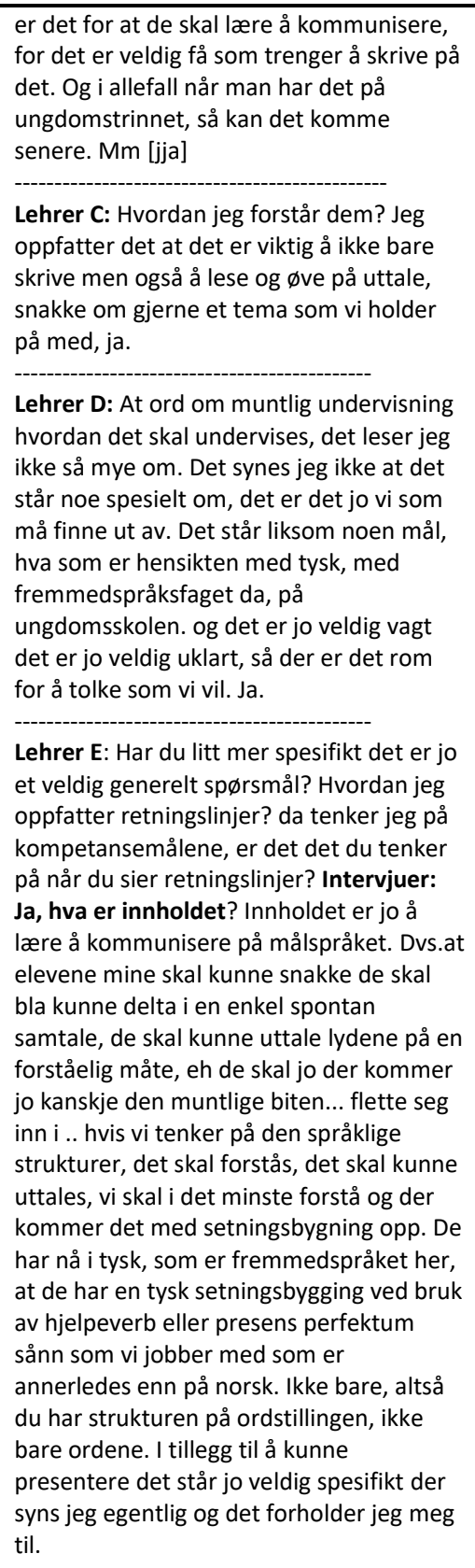 & & \\
\hline $\begin{array}{l}\text { Forschu } \\
\text { ngs- } \\
\text { frage } 2\end{array}$ & F2-1 & $\begin{array}{l}\text { Lehrer A: Ikke alltid. Men altså et } \\
\text { overordnet mål er at alle skal snakke i } \\
\text { hver time. Som regel leser de vel og } \\
\text { skriver ja, Men at de får snakket. Men jeg } \\
\text { tenker også at det er lurt med litt } \\
\text { variasjon sånn at det blir ikke det samme } \\
\text { hver gang. For de liker jo ofte også å } \\
\text { snakke med forskjellige elever også derfor } \\
\text { flytter jeg ofte rund på dem. Men jeg gjør } \\
\text { ikke det samme i hver time i forhold til } \\
\text { muntlig aktivitet. Jeg prøver å variere det. } \\
\text { Men det er ikke alltid så lett å få dem i } \\
\text { gang. Men jeg synes ofte hvis jeg gir dem } \\
\text { tid også ...hvis vi sier to minutter } \\
\text { forberedelse og så skal dere prate i to }\end{array}$ & $\begin{array}{l}\text { Viele der Lehrer sind darauf bedacht, } \\
\text { dass alle im Unterricht mitkommen } \\
\text { sollen. Sie reden wenig über } \\
\text { Differenzierung und individuelle } \\
\text { Voraussetzungen } \\
\text { (Fähigkeiten/Fertigkeiten), die Sprache } \\
\text { gut lernen zu können. Viele Lehrer heben } \\
\text { hervor, dass die Lernenden sich } \\
\text { vorbereiten dürfen müssen A, C } \\
\text { Variierter Unterricht A } \\
\text { Spontane Gespräche A, B } \\
\text { Speed-dating A, B } \\
\text { Aufsummieren A, } \\
\text { Kreisspiel A, } \\
\text { Aus dem Leben } \\
\text { Restaurantbesuch B }\end{array}$ & $\begin{array}{l}\text { Viele Lehrer } \\
\text { interessieren sich für } \\
\text { Theorien, aber soweit } \\
\text { fehlt eine allumfassende } \\
\text { Theorie des } \\
\text { Spracherwerbs einer } \\
\text { zweiten Sprache, dh sie } \\
\text { müssen bei der } \\
\text { Unterrichtsplanung und } \\
\text { Benotung ohne } \\
\text { auskommen (Lightbow } \\
\text { \& Spada) } \\
\text { Variierter Unterricht ist } \\
\text { wichtig, kooperative } \\
\text { Aktivitäten und }\end{array}$ \\
\hline
\end{tabular}




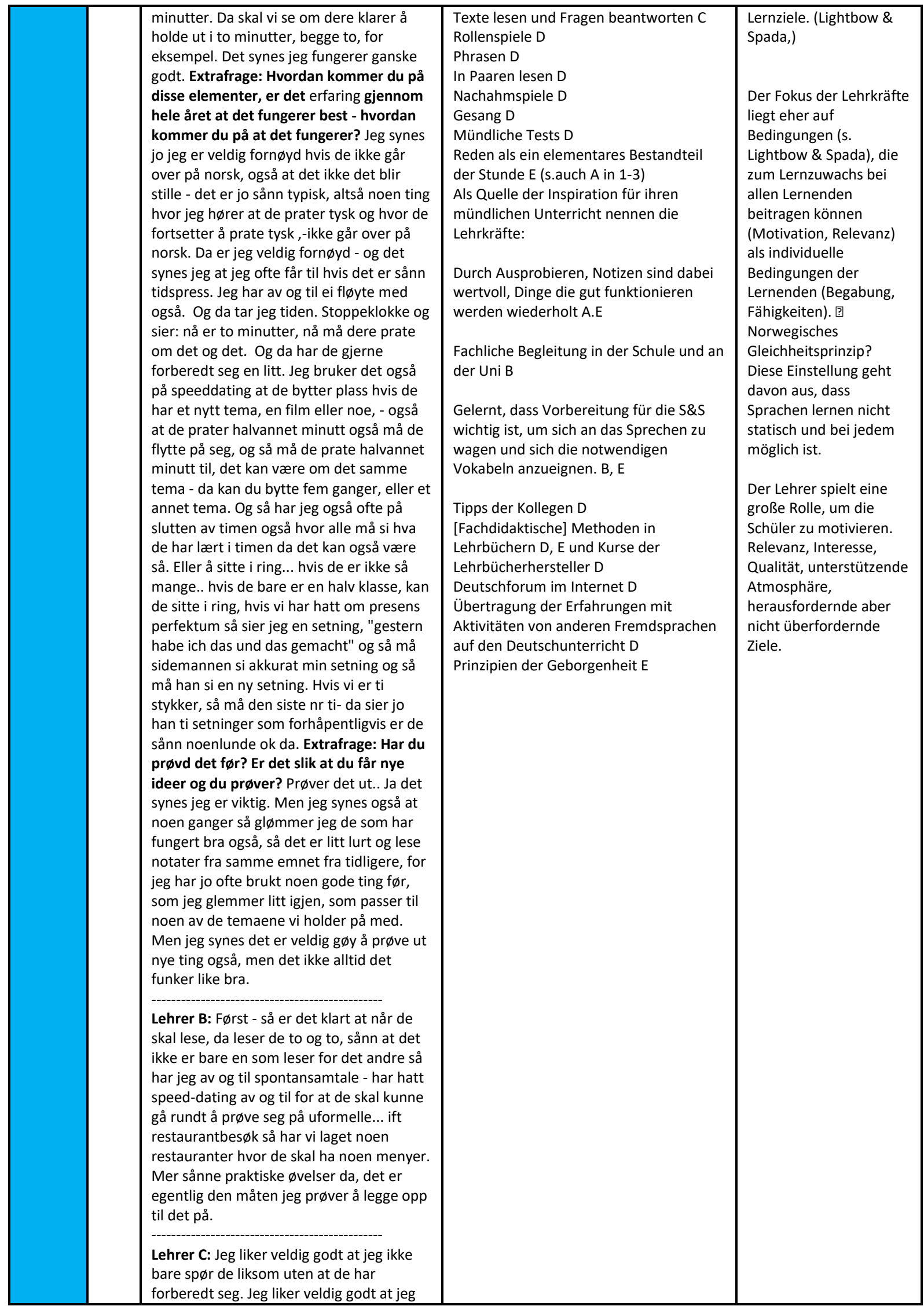




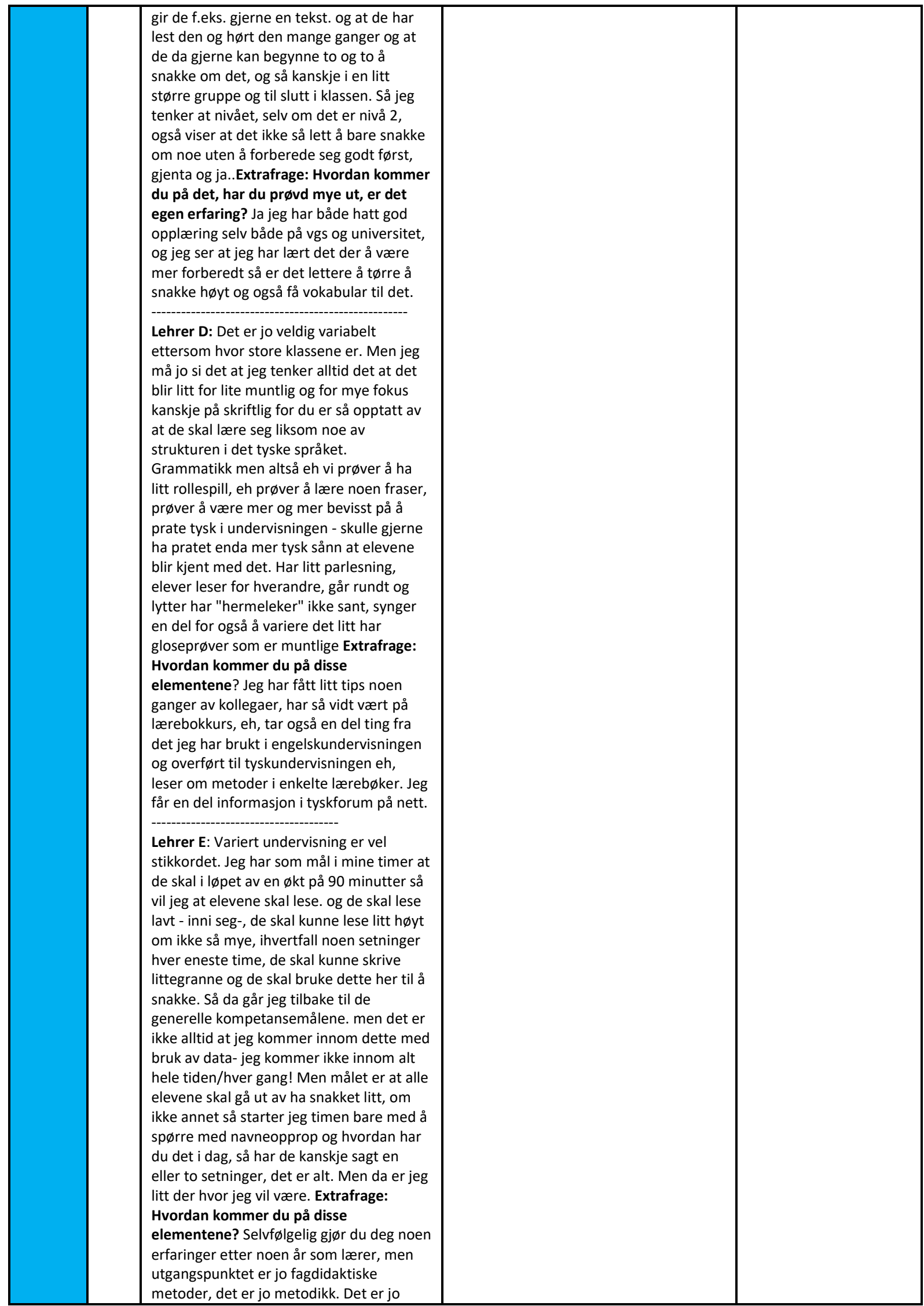




\begin{tabular}{|c|c|c|c|}
\hline & $\begin{array}{l}\text { hvordan få en elev til å snakke. } \\
\text { Erfaringsmessig så ser jeg at hvis jeg } \\
\text { samtaler med en elev, så gjør jeg det ikke } \\
\text { alene foran klassen, målet er ikke at alle } \\
\text { skal si noe høyt overfor resten av klassen. } \\
\text { Skape trygghet. Okay, alle sammen jobber } \\
\text { to og to. Snakk sammen, dette er } \\
\text { oppgaven. kanskje legge opp på tavla, } \\
\text { eller en forberedt oppgave eller spørsmål } \\
\text { kanskje ferdigstilte spørsmål. Noen ganger } \\
\text { må de lage spørsmålene selv ut fra ord de } \\
\text { har jobbet med, eller ja ordforråd de har } \\
\text { jobbet med, så det varierer veldig, men } \\
\text { jeg ligger litt sånn, det kan være at det er } \\
\text { feil, men jeg har egentlig litt sånne } \\
\text { prinsipper etter det jeg har gjort som jeg } \\
\text { har endret på etter erfaring at barn skal } \\
\text { ikke snakke høyt foran klassen. Det har jeg } \\
\text { nesten gått helt bort ifra. Det kan være } \\
\text { feil, men jeg opplever i allefall en større } \\
\text { trygghet og hvis de skal snakke litt sånn } \\
\text { ovenfor hverandre, overfor to eller to, } \\
\text { eller fire og fire, så bygger jeg opp. Først } \\
\text { kanskje skrive litt, tenke litt igjennom, da } \\
\text { får du ikke det spontane, så er det to og } \\
\text { to, også snur to og to seg og snakker } \\
\text { sammen så det blir fire og fire også er det } \\
\text { en runde rundt. Kanskje kan jeg være tøff } \\
\text { nok til å utvide det her til seks eller åtte i } \\
\text { gruppa men aldri alene foran en hel } \\
\text { klasse, aldri høytlesning alene. Fordi der } \\
\text { sitter det elever som synes det er fælt å } \\
\text { lese høyt på norsk. OK... Så det slipper } \\
\text { mine elever og jeg opplever at jeg får flere } \\
\text { til å bruke språket på den måten. Det er } \\
\text { litt lettere å dumme seg ut for en isteden } \\
\text { for tyve. }\end{array}$ & & \\
\hline F2-2 & 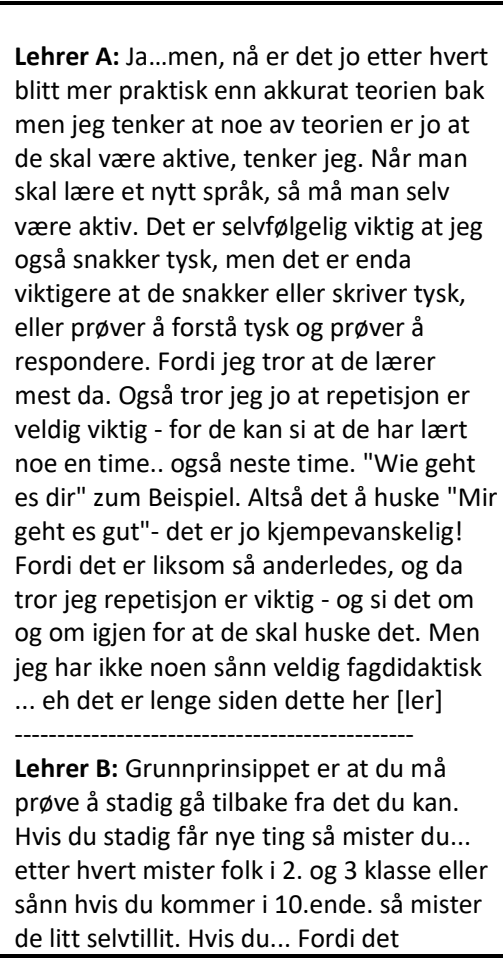 & $\begin{array}{l}\text { Theorien sind zweitrangig, Praxis steht im } \\
\text { Vordergrund. Schlagwortartig werden } \\
\text { allgemeine pädagogische Prinzipien wie } \\
\text { die kognitive Meisterlehre und das } \\
\text { didaktische Relationsmodell erwähnt, } \\
\text { fachdidaktisch wird auf die Nutzung von } \\
\text { Phrasen eingegangen. } \\
\text { Es wird eher erzählt, was die Lehrer } \\
\text { tatsächlich selbst als wichtig erachten } \\
\text { (aktiv sein, Repetition von Inhalten } \\
\text { (Lehrer A \& B), variierter Unterricht, } \\
\text { Geborgenheit) } \\
\text { Schüler sollen selbst aktiv sein A, D } \\
\text { Lehrer muss die Sprache reden A } \\
\text { (modellernen wird nicht erwähnt) } \\
\text { Repetition A, vom Bekannten ausgehen B } \\
\text { Didaktisches Relationsmodell B } \\
\text { Pauken C (wer paukt ist vorbereitet) } \\
\text { Chunks \& Phrasen C (evt auch A (und D)) } \\
\text { Vorbereitet sein C } \\
\text { Nachahmen - „Meisterlehre“ benannt D } \\
\text { Mit eigenen Worten formulieren D } \\
\text { Digitale Möglichkeiten, (auch Teil der } \\
\text { Lernziele), Film, screencastomatic D, } \\
\text { insbesondere E }\end{array}$ & $\begin{array}{l}\text { Teorien sind } \\
\text { zweitrangig, Praksis } \\
\text { steht im Vordergrund } \\
\text { (Subjektive Theorien der } \\
\text { Lehrkräfte (A. Helmke, } \\
\text { 2004) Praktische } \\
\text { Berufstheorie, Lauvås \& } \\
\text { Handal). } \\
\text { Geborgenheit und } \\
\text { Relationen sind wichtig, } \\
\text { damit die S\&S sich } \\
\text { trauen (Bjørke \& Grønn, } \\
\text { s. 93; Deci \& Ryan, 1993) } \\
\text { Digitale Möglichkeiten } \\
\text { (auch Teil der Lernziele) } \\
\text { Bjørke \& Grønn, s87) }\end{array}$ \\
\hline
\end{tabular}


Nordic Journal of Modern Language Methodology

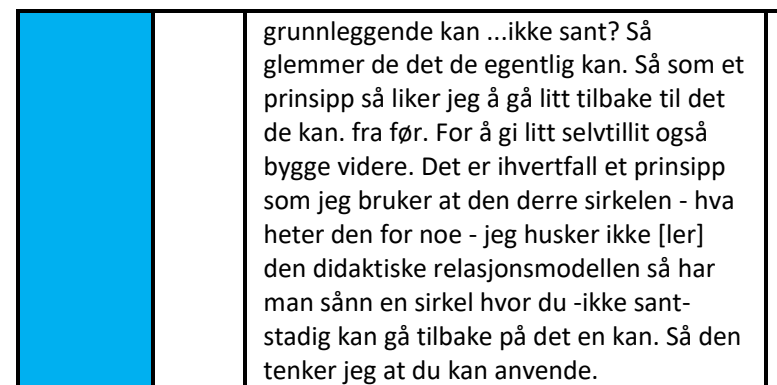

Lehrer C: Jeg har gått litt mer tilbake til pugging faktisk. Og noe jeg bruker spesielt som jeg har lært meg i to år nå, det er sånne chunks -at de lærer fraser f.eks. og det vil jeg gjerne at de skal pugge disse frasene isteden for gloser. Da mener jeg at de har større forutsetninger for å kunne si ikke bare enstavelsesord men at de lettere kan snakke og det er igjen tilbake til det at å pugge i forkant er en god måte å få elevene til å snakke på, å være godt forberedt på det en gjør. Jeg har ikke tro på å snakke om noe helt ukjent, det mener jeg de ikke har vokabular til. Så jeg synes det med forberedelse at det er en metode som jeg setter høyt hos meg, og at de $\varnothing v e r$ - ikke sant -to og to før de sier noe høyt og sånn.

Lehrer D: Det er jo veldig viktig at eleven skal være deltagende, da. Så at den skal bli aktivisert. Eh ikke bare lytte. Er veldig opptatt av skal bruke alle ferdigheter ikke sant- i språk. Altså når du da har lytte skrive lese snakke, så det er klart så blir det naturlig nok endel snakking og lytte som kanskje er de som er veldig vesentlige ift muntlig, selv om ja lese og forsåvidt så eh har nok litt en skulle kanskje, altså mesterlære er jo en egen holdt jeg på å si det er jo egentlig en sånn måte å

undervise på eller veilede på for den saks skyld og det er jo det du gjør med elevene du veileder Så den derre mesterlæren hvor elevene hermer, den har jeg veldig tro på i fremmedspråk. Men så er jeg jo veldig opptatt av det går jo mer i retning av men du kan jo ikke kalle det muntlig så mye da, men det der at elevene også skal kunne forske og tenke litt selv for å finne sine ord og finne forståelsen bak, det syns jeg er fint og blande inn det og da. men det er jo noe du kan bruke både i muntlig og skriftlig. Vi har jo begynt mye i det siste da det med når de har så gode digtale holdt på å si -utstyr elevene da, at de mer og mer leser inn på bånd - eh ikke på bånd men hva heter det da aja lydfiler, og det er klart da er det jo veldig greit å klare å vurdere flere og gi en personlig tilbakemelding.

Lehrer E: Må jeg inn på den teorien som ikke sitter fremme i hodet her som du
Geborgenheit und Relationen sind wichtig, damit die Schüler sich trauen, Lustprinzip E

Herausforderungen:

Zeit $\mathrm{E}$

Spontane Gespräche E

Individuelle Arbeit schwierig für

schwächere Schüler vs. Gruppenarbeit -

"Trittbrettfahrer" E 
Nordic Journal of Modern Language Methodology

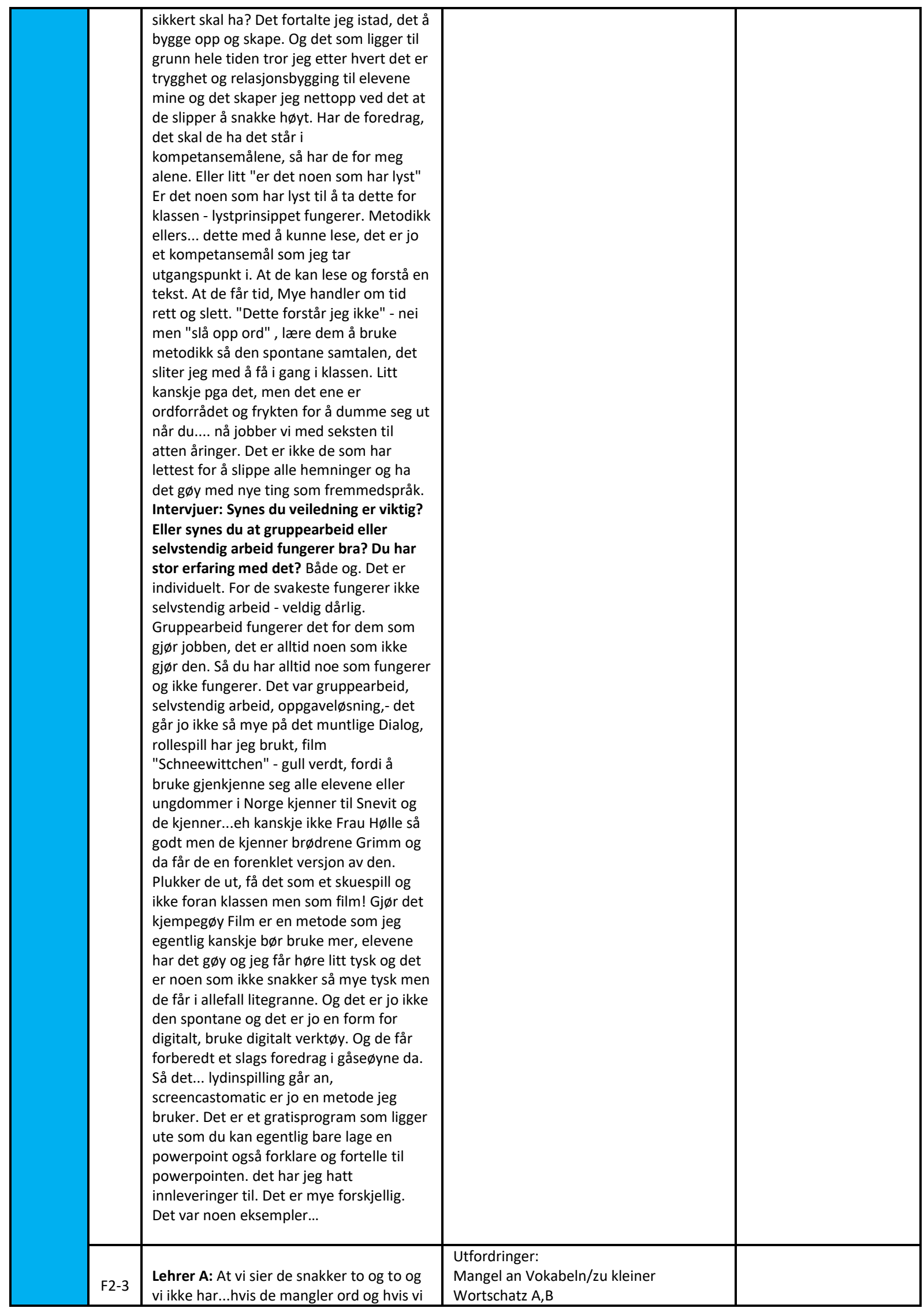




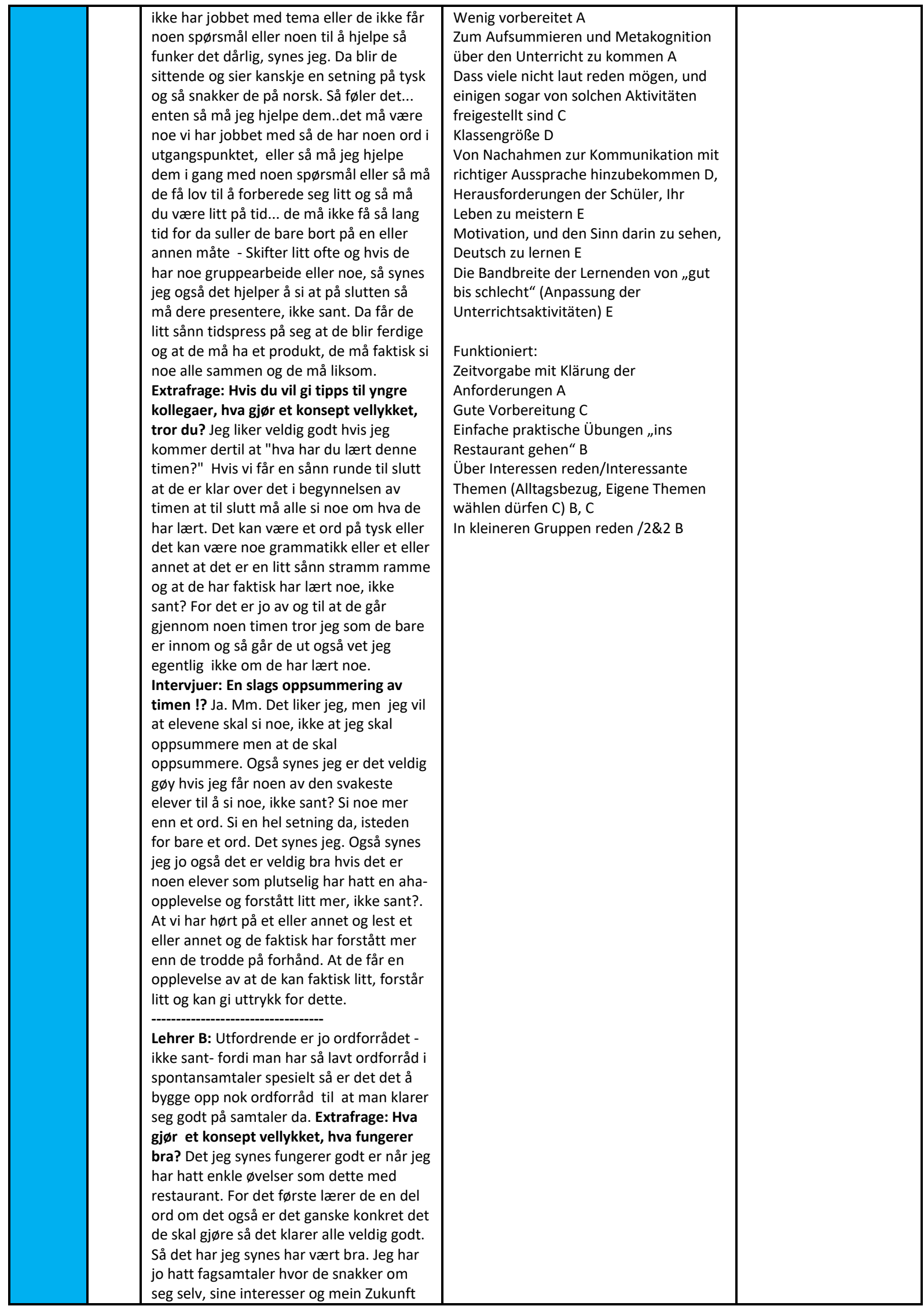




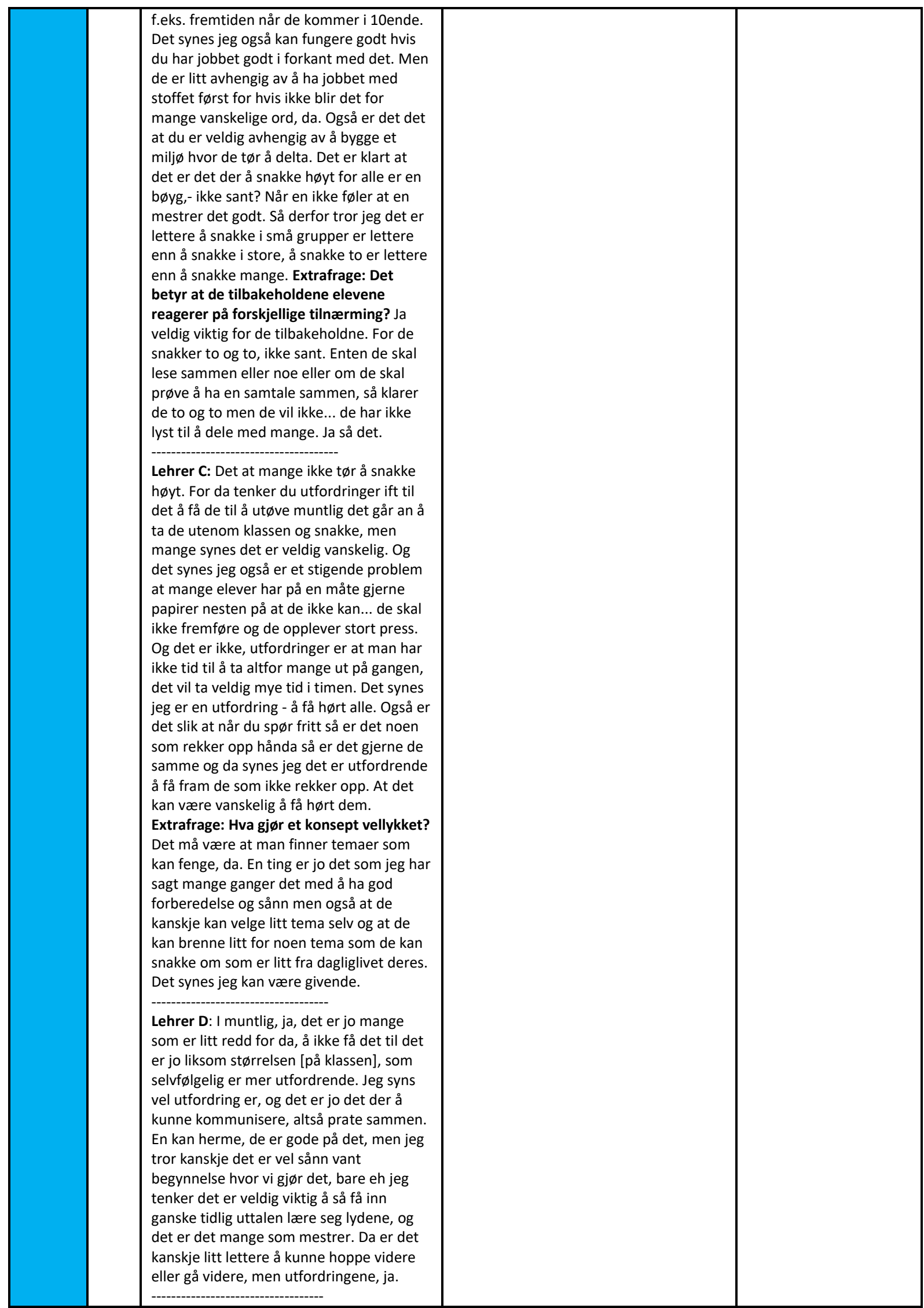


Nordic Journal of Modern Language Methodology

2019, 7 (1), 116-165 (Part B - Not peer reviewed)

\begin{tabular}{|c|c|c|c|c|}
\hline & & $\begin{array}{l}\text { Lehrer E: Det utfordrende er jo de } \\
\text { svakeste, de faglig svakeste elevene, de } \\
\text { som er utrygge. Vi har jo også... alle er } \\
\text { ikke mennesker A4. mange sliter med mye } \\
\text { utfordringer er jo rundt omkring, andre } \\
\text { ting. de kommer på skolen med hodet fullt } \\
\text { av andre ting. Så skal de lære et } \\
\text { fremmedspråk som krever mye } \\
\text { motivasjon. For de ser ikke hensikten med } \\
\text { dette. Vi kan likså godt snakke engelsk. Så } \\
\text { utfordringen min er ofte og den samtalen } \\
\text { tar jeg ganske mange ganger med elevene } \\
\text { mine. Hvorfor skal vi lære dette? Men det } \\
\text { er jo ikke bare språk. Det har jo noe med } \\
\text { kultur å gjøre, det har med } \\
\text { kommunikasjon.. det har med at vi er fire } \\
\text { millioner og vi må forholde oss til resten } \\
\text { av verden. Så den der biten der er jo } \\
\text { ganske viktig. Også er det selvfølgelig } \\
\text { utfordringa er alltid du har noen som er } \\
\text { gode, du har noen femmere og seksere, } \\
\text { du har en del som stryker. Det spennet } \\
\text { mellom elevene. Det gjelder i } \\
\text { fremmedspråk som i andre fag. Det er } \\
\text { utfordrende, hvor fort de jobber, } \\
\text { undervisningsopplegg som passer alle. }\end{array}$ & & \\
\hline $\begin{array}{l}\text { Forschu } \\
\text { ngs- } \\
\text { frage } 3\end{array}$ & F3-1 & $\begin{array}{l}\text { Lehrer A: Utfordringen er jo...Det er } \\
\text { mange utfordringer - men jeg tror nok at } \\
\text { jeg snakket mer tysk i begynnelsen av min } \\
\text { karriere. Jeg tror nok dessverre jeg } \\
\text { snakker litt mindre tysk nå i timene, det er } \\
\text { synes jeg jo er dumt. Men der tror jeg nok } \\
\text { også at som lærer blir en også veldig trøtt } \\
\text { av det når det er en del svake elever som } \\
\text { ikke skjønner noen ting og som bare sier } \\
\text { "HÆEÆEÆ". n blir litt sånn demotiviert av } \\
\text { det derre "forstår ikke hva du sier - hva var } \\
\text { det du sa nå" liksom. Det er en utfordring, } \\
\text { ehmmmm - og det er utfordring å finne } \\
\text { gode oppgaver eller gode metoder for å få } \\
\text { de til å prate mer selv også. Jeg synes det. } \\
\text { Fordi de faller veldig fort tilbake igjen til } \\
\text { norsken. Også synes jeg også det er en } \\
\text { utfordring å få det til å bli gøy, ikke sant? } \\
\text { Ja, fordi jo gøyere de synes det er - da er } \\
\text { de jo mer på hugget, ikke sant? Det er } \\
\text { ikke alltid så lett å få det til. Men jeg synes } \\
\text { av og til det der når jeg har speedating og } \\
\text { de sitter og jeg lager en sånn rekke og har } \\
\text { fløyte og de må flytte rundt, det liker de. } \\
\text { De liker det når de må snakke med } \\
\text { forskjellige og når de kjenner det } \\
\text { konseptet på en måte og bare det å flytte } \\
\text { vekk stoler...å lage noen annet, det virker } \\
\text { det som de liker.. Men jeg synes ikke det } \\
\text { er lett å lage tyskundervisningen gøy fordi } \\
\text { at eksamen er jo liksom der i bakgrunnen } \\
\text { og ...da blir det nødvendigvis en del } \\
\text { skriftlig og noen ganger skulle jeg ønske at } \\
\text { vi hadde undervisning som ikke handler } \\
\text { om eksamen eller ikke avsluttende } \\
\text { eksamen. Det synes jeg hadde vært gøy - } \\
\text { bare lære tysk bare for gøy! Extrafrage: } \\
\text { Hva synes du om nivået når de kommer }\end{array}$ & $\begin{array}{l}\text { Bezug zur Problemstellung: Früher mehr } \\
\text { Deutsch geredet als jetzt - } \\
\text { desillusioniert, viele verstehen nicht. A, B } \\
\text { Schwierig, gute Aufgaben und gute } \\
\text { Methoden, die zum Sprechen der } \\
\text { deutschen Sprache anregen A } \\
\text { Schwierig, es spaßig hinzubekommen, } \\
\text { Abschlussprüfung lauert im Hintergrund } \\
\text { A } \\
\text { Schwierig, weil Schüler werden wenig } \\
\text { exponiert ggü der Sprache (vgl Englisch) } \\
\text { Zu wenig Zeit für mündliche Aktivitäten } \\
\text { (vs der Grammatik C, schriftlich E) B, C, E } \\
\text { Schwierig, Schüler die Atmosphäre } \\
\text { bereitzulegen, damit sie verstehen, dass } \\
\text { auch Fehler erlaubt sind, dass andere } \\
\text { Normen für Gesprochenes gelten D }\end{array}$ & $\begin{array}{l}\text { Bjørke og Grønn s.83 } \\
\text { heben hervor, dass die } \\
\text { mündliche Sprache eine } \\
\text { eigene Logik und eigene } \\
\text { Regeln besitzt und dass } \\
\text { einige daher davon } \\
\text { abraten, die Normen der } \\
\text { Schriftsprache auf die } \\
\text { mündliche Sprache zu } \\
\text { übertragen. Dies könne } \\
\text { die Schüler in ihrem } \\
\text { Lernprozess hemmen. } \\
\text { Ingen av lærerne sier at } \\
\text { det ligger andre normer } \\
\text { til grunn for muntlig } \\
\text { preget undervisning, } \\
\text { men lærer D sier at } \\
\text { hun/han oppmuntrer til } \\
\text { å snakke i vei "hopp i } \\
\text { det, kom igjen, prat i } \\
\text { vei, prat med litt norske } \\
\text { ord" }\end{array}$ \\
\hline
\end{tabular}


Nordic Journal of Modern Language Methodology

2019, 7 (1), 116-165 (Part B - Not peer reviewed)

fra ungdomsskolen, det gjelder sikkert spesielt dem som hadde tysk på ungdomsskolen. Synes du er greit å ha muntlig-kommunikativt opplegg, når de kommer opp her på videregående? Altså på nivå II? Ja, de forstår jo mer, selvfølgelig gjør de det. Absolutt. Og i år har jeg jo en liten gruppe sånn at de forstår mye mer tysk enn de andre. Og de er nok også litt mer interessert. Og de er jo gode til å prate i vei altså. Mange av de. Da flytter jeg gjerne også rundt på dem. De sitter jo to og to, og så sier jeg at den innerste sirkelen - dere må flytte et hakk og så sitter bare med noen nye. Det tror jeg de synes er litt ok. Så blir de litt tryggere og så lærer de litt av hverandre, og så ja.

Lehrer B: Uff- det var vanskelig må tenke på - Først er jo det at hvis jeg snakker mye tysk så vil jo ikke alle forstå alt, så utfordringen er at en skulle gjerne ha snakket enda mer, ikke sant? Tysk bare som lærer i undervisninga. Så en utfordring er ren forståelse av ord. Og problemet med tysk er at du blir så lite eksponert for språket, at de ikke får et stort nok ordforråd nok til å kunne bruke språket ordentlig, da. Utfordringen er at du rett og slett ikke har nok tid til å holde på med muntlige aktiviteter kanskje. Intervjuer: Engelsk, f. eks. er du eksponert i TV.... : Hele tiden, også har vi hatt det veldig mye lenger. Men det er klart at de ser så mye engelske filmer og de spiller så mange engelske spill at det engelske får de jo gratis, nesten. Det blir på en helt annen måte da.

Lehrer C: Stort press på at de skal skrive bra, veldig mye grammatikk som elevene sliter mye med en føler at en har liten tid ift alt som forventes av disse

kompetansemålene og de fleste prøver erdet burde de jo egentlig ikke være - men de er ofte mest skriftlige og da øver man mest til skriftlig. Så det ene er tiden som vanskeliggjør dette synes jeg.

Lehrer D: Det er jo det at du kan jo ikke prate med alle sammen samtidig og du får jo liksom lyttet på noen. Noen er jo såpass forsiktig at de tør ikke, ikke sant? Jeg har jo av og til hvor de da liksom skal vise rollespill og sånn, så er det mange som ikke $t ø r$ å vise for de andre. Så det er kanskje den største utfordringen. Og når det er store klasser så er det jo vanskelig å veilede og vise dem. Men jeg tenker at.... det ser jeg mer og mer selv at jeg kanskje skal jeg sier jo stadig vekk "hopp i det, kom igjen, prat i vei, prat med litt norske ord" bare for å tørre og tenke at det er ikke så viktig om det er litt feil, og så er det det at det er vanskelig fordi at de 
Nordic Journal of Modern Language Methodology

2019, 7 (1), 116-165 (Part B - Not peer reviewed)

\begin{tabular}{|c|c|c|c|}
\hline & $\begin{array}{l}\text { liksom,- du er litt mer nøye når du skriver, } \\
\text { ikke så nøye når de skal .[snakke]...så. } \\
\text {--ohrer E: Der kommer også, jeg skulle hatt } \\
\text { Lobbelt så mye tid så skulle elevene mine } \\
\text { lært mye tysk. Jeg tenker jo på, også synes } \\
\text { jeg også at det er veldig kort tid på å ha } \\
\text { både en muntlig og skriftlig eksamen. Jeg } \\
\text { ser jo at... jeg ser absolutt behovet for det. } \\
\text { men du verden så mye artigere språket } \\
\text { hadde vært om vi bare skulle hatt muntlig } \\
\text { f.eks. og kunne kaste det stresset med å } \\
\text { kunne skrive og produsere tekst. For det } \\
\text { er jo det de fleste elevene ... også på } \\
\text { grunn-nivået... skulle man jo... jeg ser jo } \\
\text { egentlig for meg en inndeling... det ideeelle } \\
\text { for meg som lærer hadde vært en } \\
\text { inndeling på at okay vi jobber muntlig... på } \\
\text { nivå en så er det muntlig eksamen } \\
\text { punktum, Når vi kommer på nivå to og } \\
\text { nivå tre da skal vi lære å skrive. Da har du } \\
\text { setningsstrukturer, du har lekt og du har } \\
\text { snakket og du har fått en trygghet på det } \\
\text { muntlige som jeg tror du lettere kan } \\
\text { overføre til skriftlig og da gjør vi det på } \\
\text { samme måte som vi lærer morsmålet vårt. } \\
\text { Vi begynner ikke å lære skriftlig når vi er } 2- \\
3 \text { år vi begynner med det muntlige. }\end{array}$ & & \\
\hline F3-2 & $\begin{array}{l}\text { Lehrer A: I retningslinjene står "spontan } \\
\text { samtale", er det egentlig en realisbar } \\
\text { retninglinje (og andre muntlige greier)? } \\
\text { Jeg synes jo de spontane samtaler er noe } \\
\text { av det som er enklest, men presentere } \\
\text { aktuelle og tverrfaglige emner, synes jeg } \\
\text { kan være litt vanskeligere. At de selv skal } \\
\text { finne aktuelle emner og ja, det synes jeg. } \\
\text { Gi uttrykk for opplevelser, synspunkter og } \\
\text { holdinger, det går jo an til en viss grad å få } \\
\text { til, tenker jeg. Kommunisiere med god } \\
\text { uttale og intonasjon -Det må en jo også } \\
\varnothing v e \text { på for at en skal bli forstått. Jeg tror } \\
\text { nok at vi som tysklærere også kan bli litt } \\
\text { for opphengt i at det skal være riktig men } \\
\text { jeg tenker at jeg pleier alltid å si til elevene } \\
\text { "vi er underveis" - jeg snakker ikke } \\
\text { perfekt, dere snakker ikke perfekt, vi } \\
\text { holder på å lære dette språket og da er } \\
\text { det naturlig at vi gjør feil - vi snakker jo } \\
\text { ikke riktig hele tiden. Litt å få vekk den } \\
\text { derre at alt må være så riktig alltid. At når } \\
\text { en har tenkt gjennom hele setninger, har } \\
\text { analysert setninger og da er ja ofte } \\
\text { samtalen forbi i en ekte situasjon. } \\
\text { Extrafrage: Ofte med det muntlig- } \\
\text { kommunikasjon er det elevene - Er du } \\
\text { tydlig nok å prøve at du snakker tysk med } \\
\text { dem? Ja. Jeg kunne nok ha snakket enda } \\
\text { mer. Jeg begynner jo alltid med å snakke } \\
\text { tysk og snakker om plan for timen og hva } \\
\text { vi skal gjøre. Også kommer det litt an på } \\
\text { hva vi skal gjøre. Når vi holder på med } \\
\text { grammatikk, så gå jeg fort over på norsk, } \\
\text { da sliter jeg med, - for da vil jeg så gjerne } \\
\text { at de skal forstå også. }\end{array}$ & $\begin{array}{l}\text { Aktuelle und fächerübergreifende } \\
\text { Themen sind schwierig A } \\
\text { Als Lehrer kann man sich zu viel damit } \\
\text { beschäftigen, dass alles so perfekt sein } \\
\text { soll. A } \\
\text { Bücher und Lehrpläne sind ziemlich } \\
\text { umfassend B } \\
\text { Lehrbücher veraltet - verliert an } \\
\text { Aktualität D } \\
\text { Ich müsse viel mehr Deutsch im } \\
\text { Unterricht sprechen A } \\
\text { Zu hohe Anforderungen an die Schüler } \\
\text { (Interpretieren, über Gefühle reden) C } \\
\text { Wenig Zeit, eine Sprache zu lernen. E } \\
\text { Ziele nur erreichbar für die Schüler, die } \\
\text { hoch-motiviert sind. E }\end{array}$ & Björke \& Grøn s.80 ff \\
\hline
\end{tabular}


Nordic Journal of Modern Language Methodology

2019, 7 (1), 116-165 (Part B - Not peer reviewed)

Lehrer B: Alt etter hvordan en tolker det å kunne det å beherske det å kunne

kommunisere. Jeg tror jo at du kan kommunisere selv om du bruker et engelsk ord av og til selv om du henger fast, så tror jeg jo. Jeg mener at det er realistisk at en kan beherske språket kommunikativt. Så vil det avhenge av den enkelte elev hvor godt en klarer det. Men jeg... så ja, det tror jeg jo. Men det er klart at bøkene og læreplanen er ganske omfattende, så jeg skulle gjerne sett at de hadde skrellet vekk en del. Intervjuer: Stikkord tysk grammatikk...: Du kan jo få tyske elever som ikke kan dette greiene her for det er for vanskelig når de begynner å snakke om selve grammatikken i det.

Lehrer C: Jeg synes det er for høye mål egentlig, I hvertfall når de på en måte spontant... En ting er å $\varnothing$ ve på en tekst, snakke om den, gjenfortelle den... men her... læreplanen krever faktisk også at de skal tolke, de skal snakke om følelser i forbindelse med emosjoner, det er ganske store mål sånn sett. og pga at de da gjerne ikke kommer så langt så synes jeg egentlig at det er for store krav. Ja. Extrafrage: Bedre med færre krav og fokussere det mer? Ja, det mener jeg.

Lehrer D: Å neida, men det er klart at jeg synes vel de er mulige, men jeg synes det kan være vanskelig av og til å få

gjennomført det godt nok, man har jo litt begrenset tid også. Ikke skal du få gi så veldig mye lekse heller, så ja. Extrafrage: Er retningslinjene urealistiske? At kompetansemål ikke så praksisorienterte? Nei jeg synes jo forsåvidt at de er... de er så vage, så det er hvordan du tolker det da -ikke sant- det der du skal snakke om dette her med at språk, kultur og samfunn og sånn, eh en har jo ofte tekster $i$

bøkene, de er bygd opp etter det de også, så det er øvelser der du kan bruke da, jeg synes jo det. Mange er flinke til å finne andre ting da en ting er kanskje også at nå begynner lærebøkene å bli så gamle så det er også en utfordring at det liksom ikke er autentisk språk lenger, det er .. sånn prater ikke folk lenger. Så akkurat den biten der, det kan bli litt vanskelig. Men eh, nei jeg synes liksom det der å lære dem liksom litt sånn fraser, de kan fortelle om landet sitt, ikke sant, de skal jo kunne... det er jo ganske tydelige syns jeg kompetansemål, jeg synes det altså

Lehrer E: Det er jo... det står jo...det er jo ingen det er jo lærerens skriv det står ikke hvordan jeg skal undervise det står hva jeg skal lære dem. Intervjuer: er det kompetansemål de beskriver realistiske? 


\begin{tabular}{|c|c|c|c|c|}
\hline & & $\begin{array}{l}\text { For de meget hardt arbeidende elevene, } \\
\text { vil jeg si. Men vi har et fåtall av de meget } \\
\text { hardt arbeidende elevene. jeg ser også } \\
\text { veldig forskjell på ulike læreverk, som } \\
\text { kanskje fungerer på toppskoler i Norge, } \\
\text { som vi sliter med og som blir for vanskelig } \\
\text { for de elevene som vi har.. Så vi har et } \\
\text { spenn. Og jeg skulle ønske at jeg hadde tid } \\
\text { for å gjøre mer av type lage film, lage } \\
\text { radioreportasje, lage podcast, men det } \\
\text { brukes så mye tid på å lære det } \\
\text { grunnleggende for å kunne gjøre dette, før } \\
\text { vi kommer igang med det som er gøy. Så } \\
\text { da tenker jeg på en måte er jo hvor langt } \\
\text { vil....for kompetansemålene er jo åpne, } \\
\text { det er jo jeg som bestemmer hvor høyt jeg } \\
\text { skal ta dem. Og det stopper opp på et nivå } \\
\text { pga tid, synes jeg. Så det lander vel } \\
\text { kanskje tilbake på det ...realiserbare. Mye } \\
\text { er ikke realiserbart for det er liten tid å } \\
\text { lære et nytt språk på altså. }\end{array}$ & & \\
\hline $\begin{array}{l}\text { Forschu } \\
\text { ngs- } \\
\text { frage } 4\end{array}$ & F4-1 & $\begin{array}{l}\text { Lehrer A: Først og fremst at de prøver og } \\
\text { at de blir forstått, så det kan jo godt gå på } \\
\text { uttale - Jeg tenker en ting er at de prøver, } \\
\text { det behøver ikke å være riktig eller, hm, } \\
\text { men at de prøver også at de blir forstått. } \\
\text { Også at de klarer litt å holde tråden i } \\
\text { samtalen at de ikke bare slutter når de } \\
\text { ikke finner på noe mer at de prøver. Også } \\
\text { selvfølgelig at det er noe faglig innhold i } \\
\text { det de sier, nå snakker vi om for eksempel } \\
\text { "Was ist typisch Deutsch" nå må dere } \\
\text { komme litt ut over det der med "Bier" og } \\
\text { "Auto", nå kan vi snakke om noe mer, for } \\
\text { det vet dere egentlig fra før av, så innhold } \\
\text { i hva de snakker om etterhvert - men det } \\
\text { er ikke så ofte at jeg setter karakter på } \\
\text { dem når de er inne i timen. Extrafrage: } \\
\text { Men hvis de vet at du også vurderer } \\
\text { kanskje...er så at de blir stillere og } \\
\text { stillere? Er de redde å snakke tysk hvis de } \\
\text { vet at du vurderer? Om de ville være } \\
\text { redde da? Kanskje litt } \\
\text { mere...tilbakeholdene - Men det er ikke } \\
\text { så ofte at jeg sier at jeg går rundt og } \\
\text { vurderer dere hele tiden- det burde jeg } \\
\text { kanskje gjøre (hahaha) - Men jeg tar de ut } \\
\text { og de har jo presentasjoner og nå skal vi } \\
\text { ha en samtale - jeg liker egentlig samtale } \\
\text { bedre enn presentasjoner, og da er } \\
\text { overskriften "Was ist typisch deutsch" og } \\
\text { da... da synes jeg at jeg får, jeg liker ikke } \\
\text { det derre når de bare lager en } \\
\text { presentasjon ferdig, også eventuelt fått } \\
\text { noen hjemme til å hjelpe seg eller også } \\
\text { bare leser de det opp, ikke sant? Jeg liker } \\
\text { mer å ha en dialog. De kan godt ha } \\
\text { forberedt seg på noen spørsmål men } \\
\text { alikevel at jeg kan stille noen spørmål og } \\
\text { at de kan formulere noen egne setninger } \\
\text { som de ikke bare kan lese opp. Da føler jeg } \\
\text { det blir litt mer autentisk. Men en må } \\
\text { selvfølgelig øve på det med } \\
\text { presentasjoner også i forhold eksamen da. }\end{array}$ & $\begin{array}{l}\text { Kriterien zur Beurteilung der mündlichen } \\
\text { Note } \\
\text { Einsatz A } \\
\text { Sich verständlich machen A } \\
\text { Ein Gespräch führen können, Dialog A } \\
\text { Fachliche Inhalte A } \\
\text { Entwickelt Kriterien mit Schülern } \\
\text { zusammen B } \\
\text { Kommunikation B, D } \\
\text { Satzbau/ -elemente B, D } \\
\text { Aussprache B, D, (Film, Audiofiles E) } \\
\text { Mündliche Prüfung mit Vorbereitung C, E } \\
\text { Im Unterricht C } \\
\text { Wortschatz D }\end{array}$ & $\begin{array}{l}\text { Verschiedene Formen } \\
\text { der Bewertung: } \\
\text { Summative \& Formative } \\
\text { Beurteilung, formelle \& } \\
\text { informelle Beurteilung }\end{array}$ \\
\hline
\end{tabular}




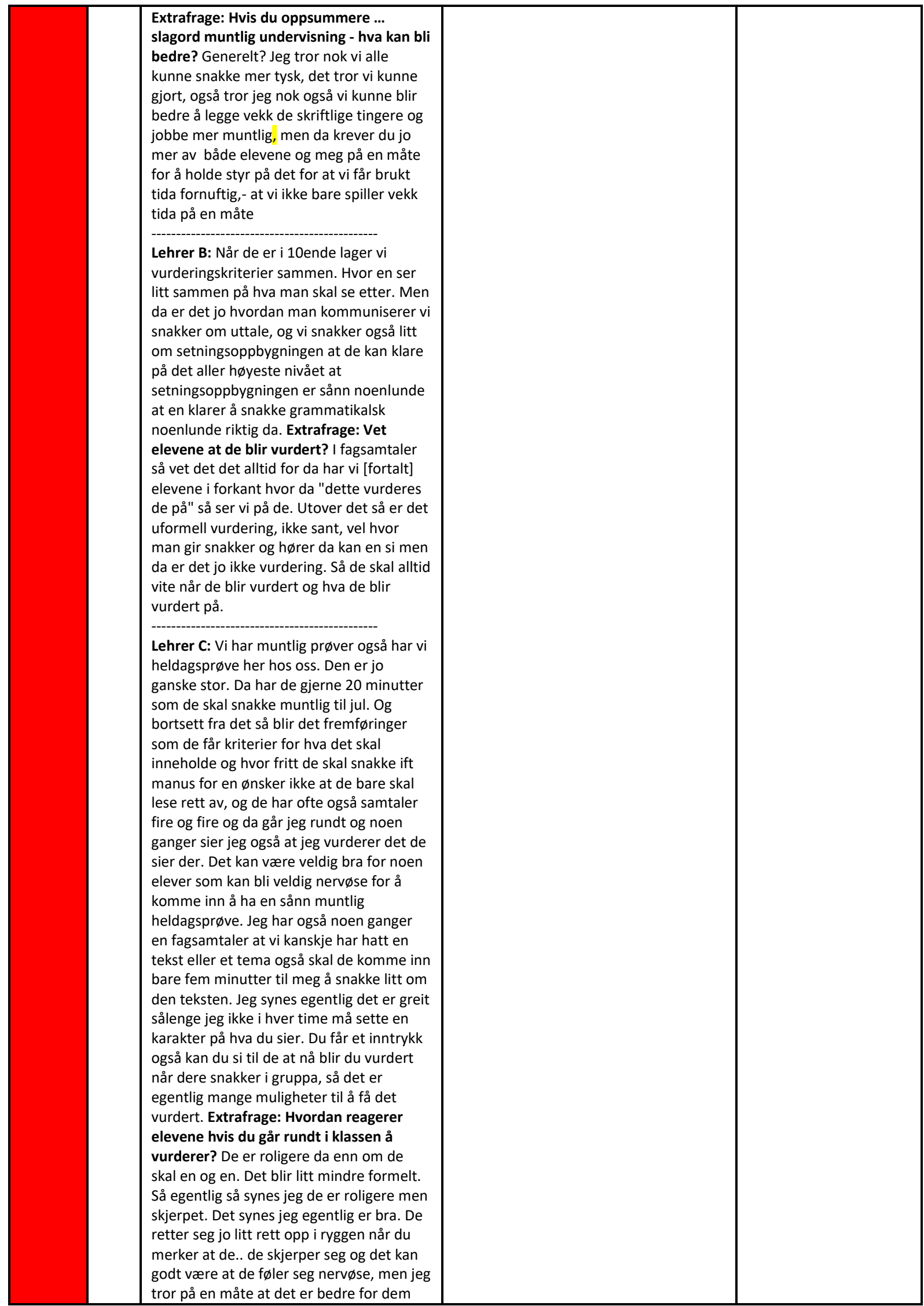




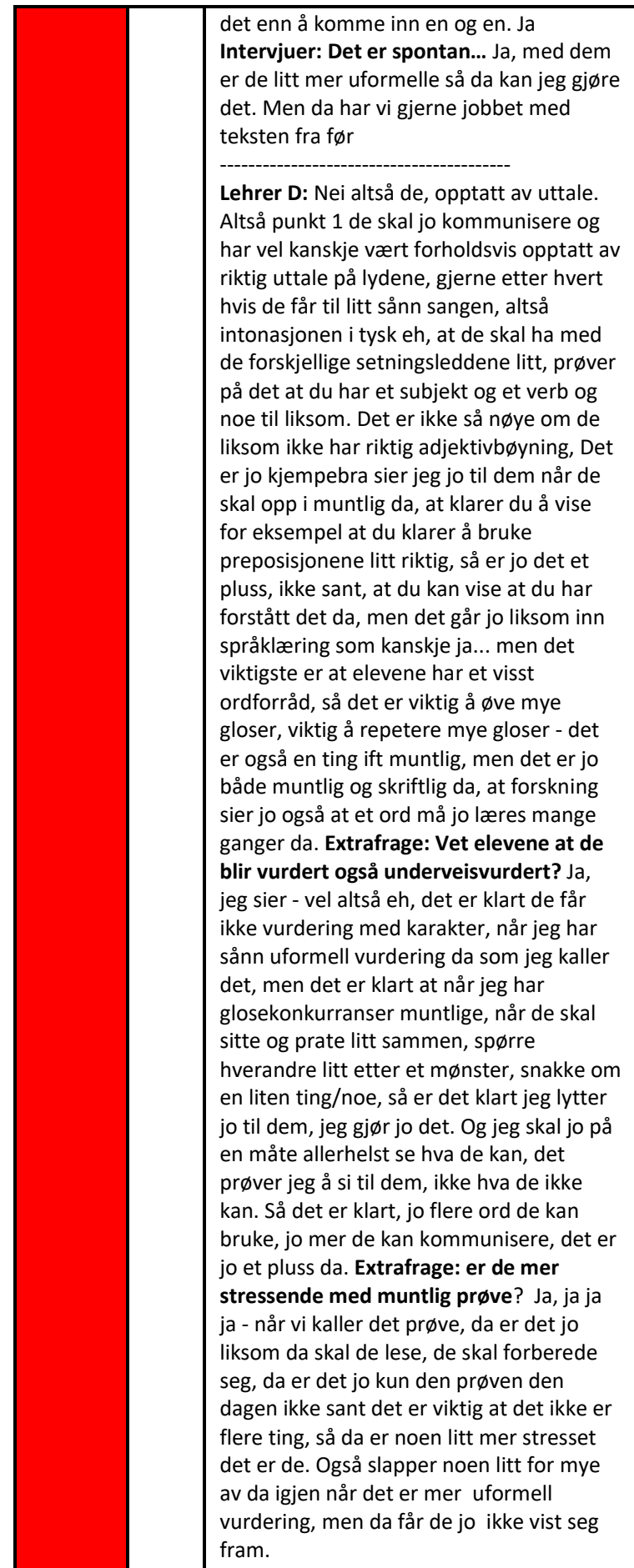

Lehrer E: Det er jo selvfølgelige muntlige prøver. Og da er det samtale med elev. Jeg kan ha en enkel samtale med en elev. De kan få lov å forberede seg til å lage en presentasjon til meg med powerpoint, den er kjedelige tradisjonelle bruker jeg ikke mye. Eh, vi kan ta utgangspunkt i en tekst. Tekstene til Wilhelm Tell - hva har du lest? kan du gjenfortelle? Ikke sant, du får vite en kjent tekst. De kan få lytte til en tekst, 


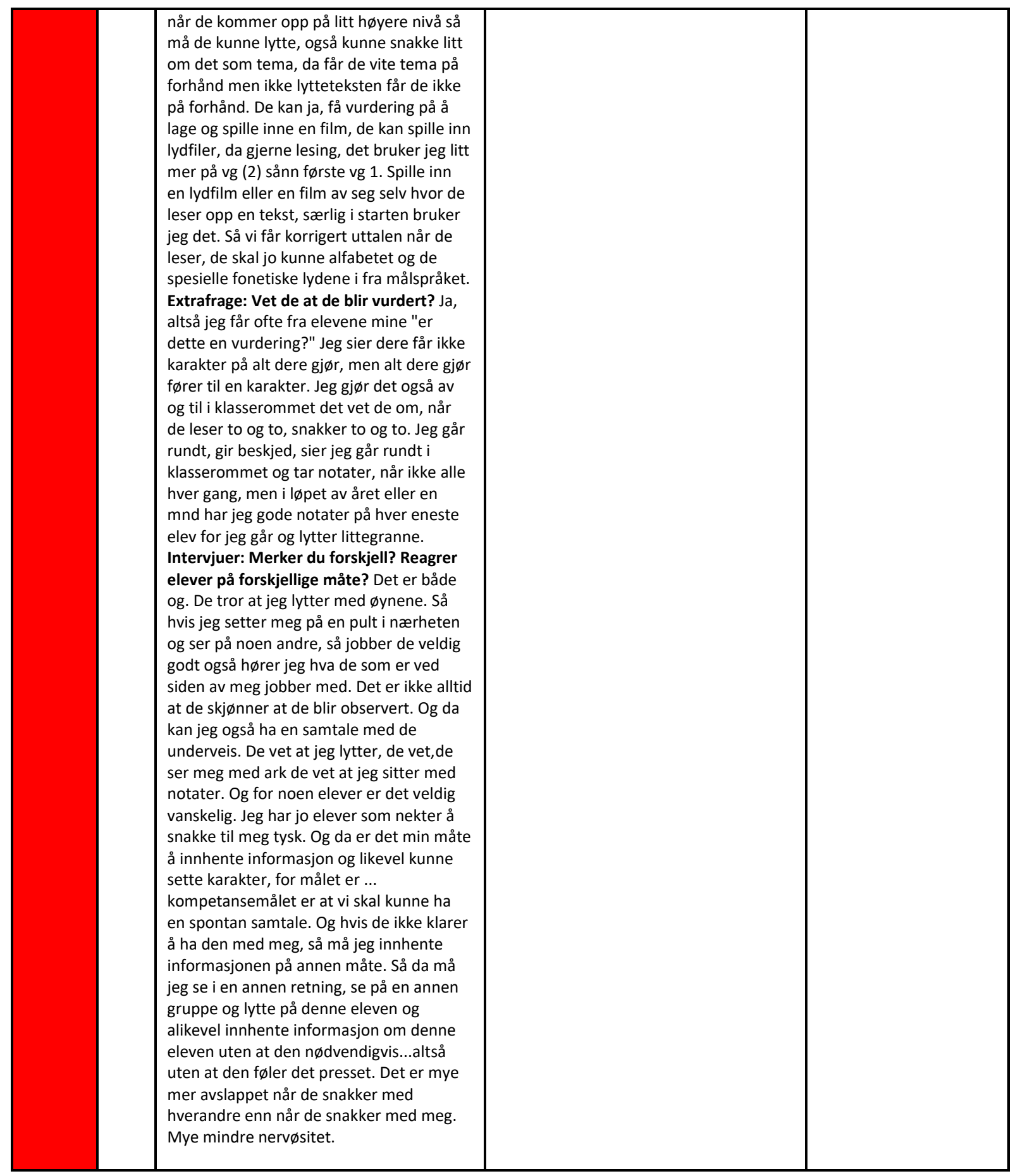

